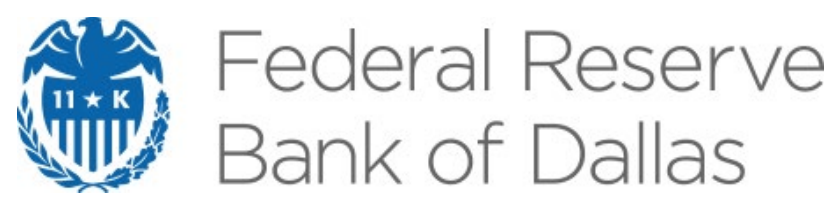

\title{
How New Fed Corporate Bond Programs Dampened the Financial Accelerator in the COVID-19 Recession
}

Michael D. Bordo and John V. Duca

Working Paper 2029

November 2020

Research Department

https://doi.org/10.24149/wp2029

Working papers from the Federal Reserve Bank of Dallas are preliminary drafts circulated for professional comment. The views in this paper are those of the authors and do not necessarily reflect the views of the Federal Reserve Bank of Dallas or the Federal Reserve System. Any errors or omissions are the responsibility of the authors. 


\title{
How New Fed Corporate Bond Programs Dampened the Financial Accelerator in the COVID-19 Recession*
}

\author{
Michael D. Bordo ${ }^{\dagger}$ and John V. Duca ${ }^{\ddagger}$
}

November 2, 2020

\begin{abstract}
In the financial crisis and recession induced by the COVID-19 pandemic, many investment-grade firms became unable to borrow from securities markets. In response, the Fed not only reopened its commercial paper funding facility but also announced it would purchase newly issued and seasoned bonds of corporations rated as investment grade before the COVID pandemic. A careful splicing of different unemployment rate series enables us to assess the effectiveness of recent Fed interventions in these longterm debt markets over long sample periods, spanning the Great Depression, Great Recession and COVID Recession. Findings indicate that the announcement of forthcoming corporate bond backstop facilities had helped stop risk premia from rising further than they had by late-March 2020. In doing so, these Fed facilities have limited the role of external finance premia in amplifying the macroeconomic impact of the COVID pandemic. Nevertheless, the corporate bond programs blend the roles of the Federal Reserve in conducting monetary policy via its balance sheet, acting as a lender of last resort and pursuing credit policies.
\end{abstract}

Keywords: financial crises, Federal Reserve, credit easing, lender of last resort, corporate bonds, corporate bond facility

JEL Codes: E51, E53, G12

\footnotetext{
"We thank Marc Giannoni, Mickey Levy, Bob McCauley, Karel Mertens, Ned Prescott and seminar participants at the Federal Reserve Bank of Dallas for useful suggestions. We thank Jonah Danziger for excellent research assistance. The views expressed are those of the authors and do not necessarily reflect the views of the Federal Reserve Bank of Dallas or the Federal Reserve System. Any remaining errors are those of the authors.

${ }^{\dagger}$ Michael D. Bordo, Rutgers University, National Bureau of Economic Research, Hoover Institute, Stanford University, bordo@econ.rutgers.edu.

†John V. Duca, Oberlin College, Dept. of Economics, 223 Rice Hall, Oberlin, OH 44074, jduca@oberlin.edu, Federal Reserve Bank of Dallas, P.O. Box 655906, Dallas, TX 75265, john.v.duca@dal.frb.org.
} 
In the financial crisis and recession induced by the Covid-19 pandemic, the ability of firms and municipal governments to borrow from securities markets dried up, as did access by small and mid-sized firms to bank loans. The massive credit squeeze risked seriously damaging the real economy via a financial accelerator mechanism. This credit squeeze was manifest in a spike in the corporate Baa-10-year Treasury bond yield spread, a long-standing measure of systemic risk (see Figure 1). In response, the Fed not only reemployed all the new tools it created during the Great Recession, but also greatly expanded its credit-easing and lender of last resort role in several ways.

This study focuses on one of them, namely the Fed's announcement that it would buy newly issued bonds of corporations rated as investment grade before the Covid pandemic. It did so with the explicit backing of the Treasury, which covered any default losses on Fed purchases of such bonds. This novel policy was not used in 2008 since without Treasury indemnification against losses, the Fed believed that the riskiness of corporate bonds implied that it did not have the requisite authority. In addition, the Fed in 2008 did not foresee the magnitude and impact of the severe widening of the corporate-Treasury bond spread, whose peak reached highs not seen since 1935 (Duca 2017). ${ }^{1}$ As Figure 1 illustrates, the spread between yields on Baa-rated corporate and 10-year Treasury bonds (BaaTr) in the recent crisis rose in line with the slightly lagging weekly insured unemployment rate until the Fed announced its corporate bond program in late March 2020.

A careful splicing of different unemployment rate series enables us to better assess the effectiveness of recent Fed interventions in the corporate bond market over a long sample that spans the Great Depression through the Great Recession and the Covid-19 Recession. Findings

\footnotetext{
${ }^{1}$ The Dodd-Frank Act of 2010 reduced the Fed's explicit authority to use 13-3 powers on its own and required Treasury approval and backing for certain actions. The 2020 corporate bond market interventions have been in accordance with the Dodd-Frank Act.
} 


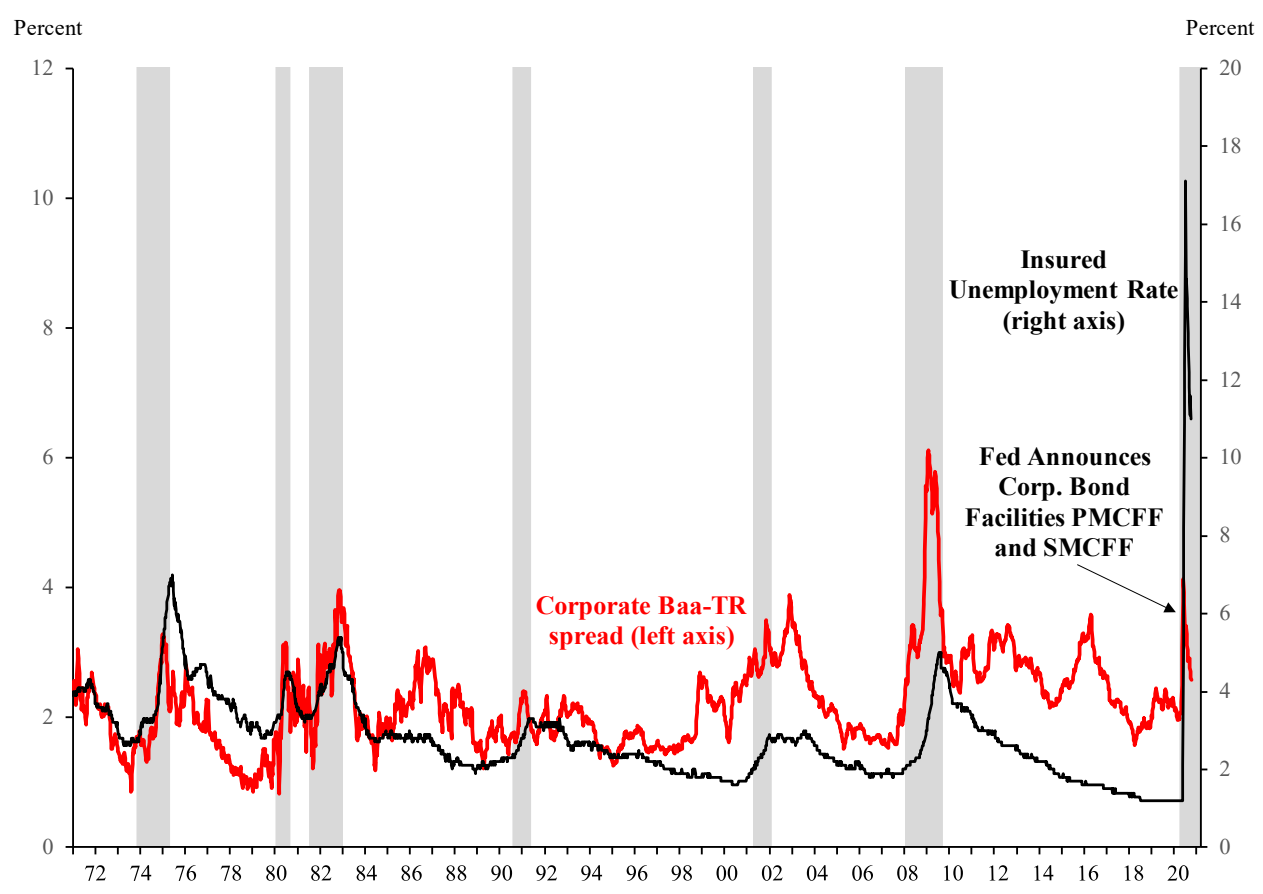

Figure 1: Yield Spread between Corporate Baa-rated and 10 Year Treasury Bonds Rise with Insured Unemployment Rate Until the Fed Announced its Corporate Bond Facilities (NBER recessions are shaded. Sources: Moody's, Federal Reserve, and authors' calculations)

indicate that the announcements of corporate bond backstop facilities had prevented corporate bond risk premiums from rising even further above pre-GFC averages than they did by late-March $2020 .^{2}$ Other results indicate that these facilities have lowered the excess bond premium component of corporate bond yields ( Gilchrist and Zakrajsek 2012). By doing so, these programs have limited the role of external finance premia in amplifying the macroeconomic impact of the Covid pandemic and the risk that a panic-induced wave of corporate bankruptcies could worsen the downturn and prolong the recovery from it. In this sense, the corporate bond interventions can be seen as a new means by which the Fed pursues its full employment and price stability objectives rather than as an expansion of its mandate. As illustrated in Figure 2, a motivation for this new

\footnotetext{
${ }^{2}$ While the Primary Market Corporate Credit Facility (PMCFF) levies an explicit 100 basis point fee over a normal spread when the Fed purchases newly issued paper, there is no explicit spread at which the Fed has purchased previously issued bonds meeting maturity and ratings criteria under the Secondary Market Corporate Credit Facility (SMCCF). Most corporate bonds purchased by the Fed have been done through the SMCCF and have been purchases of exchange-traded indexes of investment-grade bonds.
} 
tool is the rising importance of corporate bonds and the falling role of depository loans as sources of external debt finance for nonfinancial corporations. ${ }^{3}$

To present our findings, our study is organized as follows. Section 2 discusses the evolution of the Fed's response to prevent financial shocks from harming the economy via a financial accelerator mechanism. Section 3 provides detail on the Fed's announcement of two new corporate bond-buying facilities. Section 4 lays out a basic framework for modeling corporate bond premia, presenting monthly, annual, and weekly variants of these models. Section 5 discusses the data and variables, some of which are novel and extend to the 1920s. Section 6 presents empirical results and counterfactual simulations, and the conclusion provides a broader perspective on our findings.

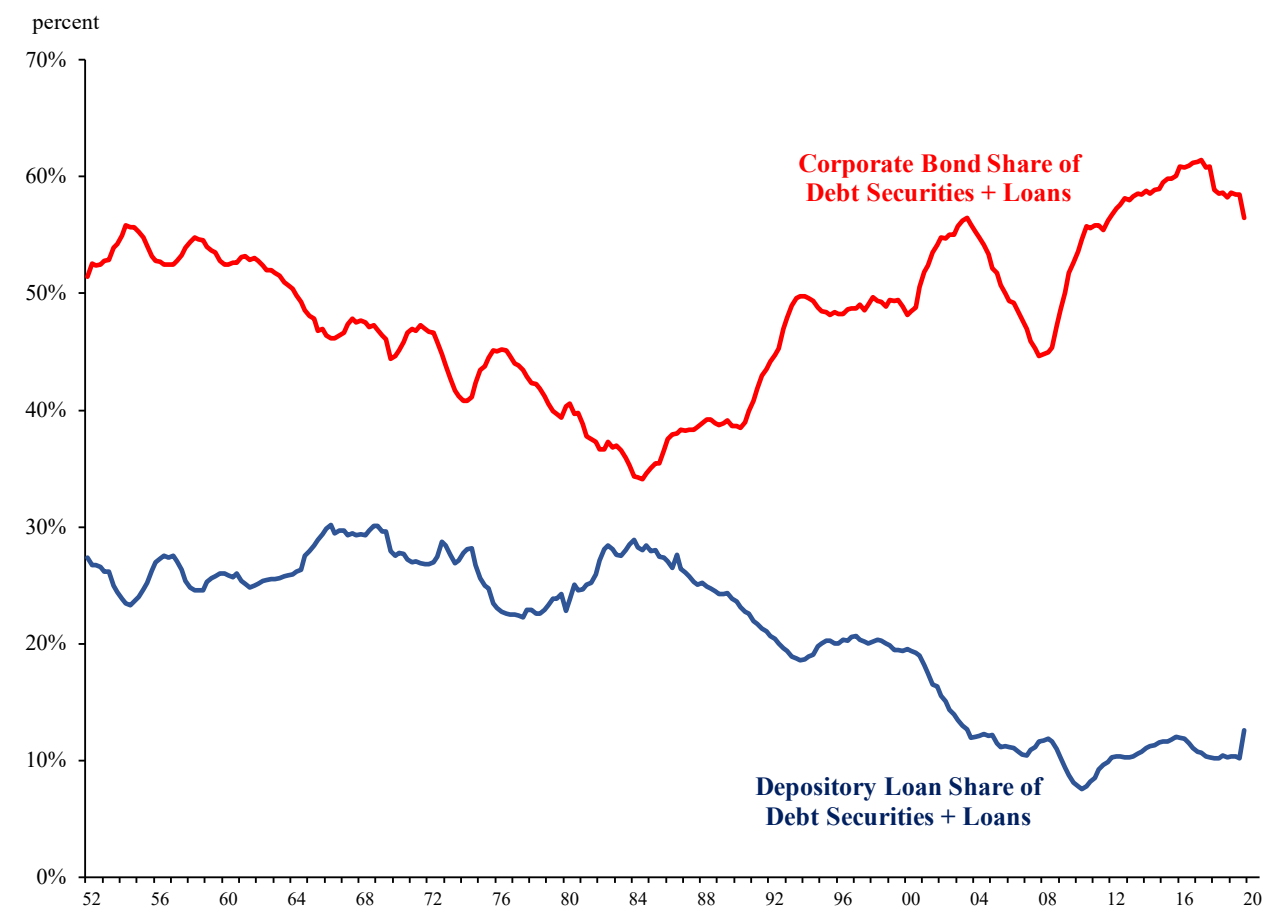

Figure 2: The Rising Role of Bonds in Debt Finance for NonFinancial Corporations (Sources: Financial Accounts of the U.S. and authors' calculations)

\footnotetext{
${ }^{3}$ The slight reversal of these trends in 2020:q1 reflected corporations tapping backup lines of credit to hoard liquidity in the face of rising uncertainty, as noted by Levy (2020).
} 


\section{The Baa-Treasury Spread, Fed Policy in Crises, and the Financial Accelerator}

The Baa-Treasury spread has long been used in analyzing the macro-economy and as a gauge of financial crises dating back to at least Friedman and Schwartz (1963). Particularly since Bernanke (1983), who used this variable to measure financial stress and the cost of credit intermediation, the spread has been made more popular by the credit and financial frictions literature, including other prominent studies by Bernanke, Gertler, and Gilchrist (1996, 1999), Bordo (2008), Mishkin (1991), and Mishkin and White (2002). ${ }^{4}$ A major reason is that this spread correlates well with banking panics, severe financial crises, extreme political shocks and other events as shown by Bordo (2008).

The Federal Reserve was founded to provide financial stability, specifically to act as a lender of last resort to prevent the kind of banking panics that plagued the national banking era (1865 to 1914). The Fed was mandated to follow well-established central banking practice (Bordo and Wheelock, 2011) and to lend freely on the basis of sound collateral (eligible bankers acceptances or commercial paper). A rule of thumb for central banks' lender of last resort policy, based on British precedent, was Bagehot's rule (1873) which stated that in the face of a banking panic a central bank was to lend freely but at a penalty rate to solvent but liquid financial institutions. Bagehot's rule also has been interpreted as lending freely to the money market and not to individual banks (Bordo 2014).

The Fed was successful in preventing a banking panic in 1920 (Gorton and Metrick 2013, Tallman and White 2020) and the New York Fed successfully provided liquidity to the New York money center banks during the October 1929 Wall Street Crash to prevent a panic (Friedman and Schwartz 1963). However, the Fed was extremely very unsuccessful in preventing four banking

\footnotetext{
${ }^{4}$ See Gilchrist and Zakrajsek (2012) for an important refinement in measuring credit spreads.
} 
panics between 1930 and 1933. Friedman and Schwartz (1963) attributed the severity of the Great Contraction 1929-1933 to the effects of the banking panics in cutting the money supply by a third. Bernanke (1983) supported Friedman and Schwartz's 'money hypothesis' but argued that the banking failures propagated the depression by raising the cost of credit intermediation. The disappearance of banks largely severed the link between saving and investment that they provided.

Bernanke's focus on credit rather than money led to the concept of the 'financial accelerator" (Bernanke, Gertler and Gilchrist, 1996 and 1999). A large financial shock leading to a collapse of asset prices reduces the net worth of firms and households, which reduces the collateral available for bank loans. Commercial banks reduce their lending which reduces consumption by the household sector and investment by firms. This lowers real output and prices. These forces in turn reduce net worth and bank lending. This process leads to debt defaults and bankruptcies, which can lead to bank failures and further credit impairment. In addition, deflation leads to Irving Fisher's (1933) debt deflation, which further reduces net worth, amplifying the downward spiral. Tightening credit conditions also affect non-bank financial intermediaries and financial markets leading to a general collapse of credit. A key indicator of credit turmoil is the Baa-10 year Treasury bond spread. It is viewed as picking up not only the effects of a credit crunch leading to potential defaults, but also a shortage of liquidity as occurs in banking panics.

After the Great Contraction, important reforms to the Federal Reserve and the banking system including the creation of the Federal Deposit Insurance Corporation (FDIC) and adding Section 13.3 to the Federal Reserve Act greatly reduced the banking panic problem. Section 13.3 allowed the Federal Reserve System to lend to non- member banks and other institutions on the basis of sound collateral in "unusual and exigent circumstances." This section was designed to overcome the severe restrictions on the Fed's discount window lending during the Great 
Contraction (Bordo and Wheelock 2011). Although there were several banking crises from the 1970s to the Global Financial Crisis (GFC) these were not classic liquidity driven panics but rather solvency crises (Bordo 2014). They were addressed by fiscal bailouts and not by lender of last resort actions (Bordo and Meissner, 2016).

The Global Financial Crisis which began with a collapse in house prices and was centered in the shadow banking system involved a massive credit crunch amplified by fears of counterparties holdings of toxic financial derivatives based on mortgages of varying quality. This fear was manifest in a spike in the Baa-Treasury spread as well as other spreads, such as the TED spread (Libor-Treasury bill), the commercial paper - Treasury bill rate spreads, and the gap between the 30-year mortgage and Treasury bond interest rates. The Fed initially viewed it as a liquidity panic, and opened up and greatly expanded its discount window facilities to give an array of financial institutions access to the discount window.

The credit crunch spread through the plumbing of the financial system to the repo market in which banks funded themselves. This led the Fed to create facilities to unclog the arteries of the financial system. In particular, via the Commercial Paper Funding Facility the Fed purchased newly issued, top-grade paper and helped cap and then lower the paper-bill spread (Duca, 2013a). The Fed also bought Aaa-rated short-term debt issued by lenders via the Term Asset-Backed Securities Loan Facility, which helped keep lender funding costs and hence loan interest rates from soaring (Agarwal, et al. 2010). Moreover, the tightening of credit set in motion the financial accelerator mechanism that Bernanke $(1983,1995)$ outlined for the Great Contraction and for which Bernanke and Gertler (1990) provided theoretical underpinnings. Such considerations led the Fed to develop radical new facilities and purchase large quantities of mortgage-backed securities (MBS) to keep credit flowing through the system. 
As time went by, it became apparent that more important than a liquidity shortage was the potential insolvency of the investment and universal banks that held the toxic derivatives in off balance sheet special investment vehicles (SIVs). This problem was finally solved by the recapitalization of the banks with TARP funds following a series of stress tests, both of which also allayed fears of counterparty risk.

The March 2020 Covid-19 crisis had elements of both a liquidity crunch and a massive credit crunch reminiscent of the GFC, as households cut back on their labor hours and consumption in fear of contracting the virus and as firms cut back on investment and payrolls. This negative impulse was greatly magnified by government-mandated lockdowns. The ensuing panic can be seen as a spike in the Baa-Treasury bond spread. It became quickly apparent to the Fed that, in addition to emergency fiscal spending, massive liquidity injections would be needed to prevent not only widespread defaults, but also an unwinding of the network of credit and financial accelerator effects that would amplify the downturn.

The Fed reestablished and extended its discount window and other financial "plumbing" facilities developed in the GFC. The latter most prominently includes resuming the Commercial Paper Funding Facility and the TALF, as well as again buying large quantities of MBS. The Fed also engaged in new activities, specifically to prevent business defaults. Hence, it began to support the corporate bond market through creating two new facilities, discussed in the next section. Other novel facilities (backstopped by the Treasury) supported the municipal bond market (Municipal Liquidity Facility) and bank loans to medium size companies bought or backed by the Fed's new Main Street Lending Facilities. As we show below the programs supporting the corporate bond market - the focus of this study-were successful in preventing a further spike in the BaaTreasury bond spread. These actions likely mitigated and delayed a wave of corporate defaults that 
the bankruptcy court and financial systems would otherwise be ill prepared to suddenly address.

\section{An Overview of the Fed's New Corporate Bond Facilities}

Fed corporate bond interventions take the form of buying either newly issued investmentgrade bonds with maturities up to four years by its Primary Market Corporate Credit Facility (PMCCF) or exchange-traded funds (ETFs) invested in seasoned investment-grade bonds with remaining maturities under five years by its Secondary Market Corporate Credit Facility $(\mathrm{SMCCF}){ }^{5}$ Eligible debt is limited to that of U.S. firms with at least 95 percent of proceeds used to support U.S. operations, and is limited to nonbanks and firms not receiving other federal aid under the CARES Act of 2020.

To shield the Fed from investment losses both facilities are structured as special purpose vehicles, with each funded by Treasury equity stakes of up to $\$ 50$ billion for PMCCF and $\$ 25$ billion for SMCCF. Debt held by the Fed funds the remainder using up to 10:1 leverage for buying investment grade bonds or syndicated loans that are investment grade at time of purchase. Portfolio exposure to any one company is limited to $10 \%$ of an issuer's maximum historical outstanding bonds and to 1.5 percent of combined PMCCF and SMCCF assets. There is a combined size limit of $\$ 750$ billion on the PMCCF and SMCCF, with both initially expiring on September 30, 2020, but later extended to expire at yearend 2020. The PMCFF can buy newly issued eligible bonds at spreads over comparable maturity Treasuries in a range (minimum and maximum) based on credit rating and prevailing spreads over comparably rated bonds at the time of PMCFF purchase plus one percentage point for a facility fee. While the pricing guidelines for the SMCFF are less explicit, that facility has bought investment grade ETFs when the corporate

\footnotetext{
${ }^{5}$ Also eligible are bonds from companies that are rated one notch below investment grade that were investment grade just before the Covid pandemic hit the U.S.
} 
Baa-Treasury spread has exceeded 300 basis points. This is about 100 basis points above the historical average from 1970 up until the global financial crisis of 2007-09.

Quite notably the Baa-Treasury spreads stopped rising on March 23, 2020 when the Fed announced that it would set up the PMCFF and SMCFF. Furthermore, the subsequent purchases by the Fed were under 50 billion by the end of June 2020 - far below the limits on the size of the facilities (see Table 1) -with the vast bulk being purchases of ETFs by the SMCFF. Instead of reflecting a balance sheet effect (as with QE), this pattern reflects a strong "backstop" effect from announcing the facility by a central bank having a great ability to expand its balance sheet, with an announcement effect evident seven weeks ahead of the Fed's initial corporate bond purchase.

\section{A Model of the Baa-Treasury Spread}

The main corporate spread investigated is the gap between yields on Baa-rated corporate bonds (Moody's) and on long-term U.S. government bonds.

\subsection{Modeling the Baa-Treasury Spread Over 1929-2020}

The Baa corporate yield is available continuously on a monthly basis since 1919, along with the Aaa-rated yield series. Of these two, the Baa is more interesting and relevant because few firms are rated Aaa (only two in 2020) - making the Baa more relevant to the cross-section of firms - and because the impact of financial frictions on firm activity tends to be greater for firms that are not as resilient as Aaa-rated firms. The series on long-term Treasury yields is an update of a series on the 10-year Treasury yield spliced by Duca (2017) from three series on government yields. As shown in Figure 3, this spread (BaaTr) widens in recessions, especially in the Great Depression, Great Recession, and the Covid Recession. In addition, the corporate Baa spread tends to be coincident with business cycle peaks and troughs (Duca, 1999), consistent with new evidence in this study that a consistently measured monthly unemployment rate (UR, discussed in Section 


\section{Federal Reserve System Assets (July 7, 2020)}

\begin{tabular}{|l|r|r|}
\hline Credit and Liquidity Programs & FRS Assets (bil.) & Max. Size \\
\hline New Post-Covid Programs & & \\
\hline Corporate Bond & 43 & 750 \\
\hline Municipal Liquidity & 16 & 500 \\
\hline Paycheck Protection Program & 68 & Unlimited \\
\hline Main Street Lending & 38 & 600 \\
\hline Reopened Pre-Covid Programs & & \\
\hline Term Asset Backed Securities & 9 & 100 \\
\hline Commercial Paper Funding & 13 & Unlimited \\
\hline Money Market Mutual Fund Liquidity & 19 & Unlimited \\
\hline Primary Dealer Credit & 2 & Unlimited \\
\hline Much Larger Asset Categories & FRS Assets (bill.) & \\
\hline Total Securities & 6,145 & \\
\hline Treasuries & 4,231 & \\
\hline MBS & 1,911 & \\
\hline Memo: Total Reserve Bank Credit & $\mathbf{6 , 8 8 1}$ & \\
\hline
\end{tabular}

Table 1: The Fed's Balance Sheet in July 2020 (Source: Federal Reserve Board)

5) has tended to move with the BaaTR spread since the late 1920 s, as illustrated in Figure 3 . The effect is more nonlinear in nature, with a stronger correlation between the spread with the square of the unemployment rate than with the level, plausibly reflecting the tail risk nature of defaults and default risk on Baa-rated bonds.

Before the Fed announced its new corporate bond facilities, this corporate-Treasury spread mainly reflected a combination of not only measurable cyclical and secular risks for corporate debt and shifts in the conduct of monetary policy, but also of hard-to-forecast shocks to liquidity, default risk, and risk aversion. Time series measures or proxies for each type of factor are limited by data availability and endogeneity. ${ }^{6}$ Cyclical risks are proxied by the square of the unemployment rate

\footnotetext{
${ }^{6}$ For example, widespread central bank interventions prevent using the commercial paper bill spread (Friedman and Kuttner) after 2007 or using corporate spreads for tracking risk in modeling commercial paper (Duca, 2013) or municipal-Treasury spreads after February 2020. Endogeneity concerns also raise doubts about using the yield curve
} 


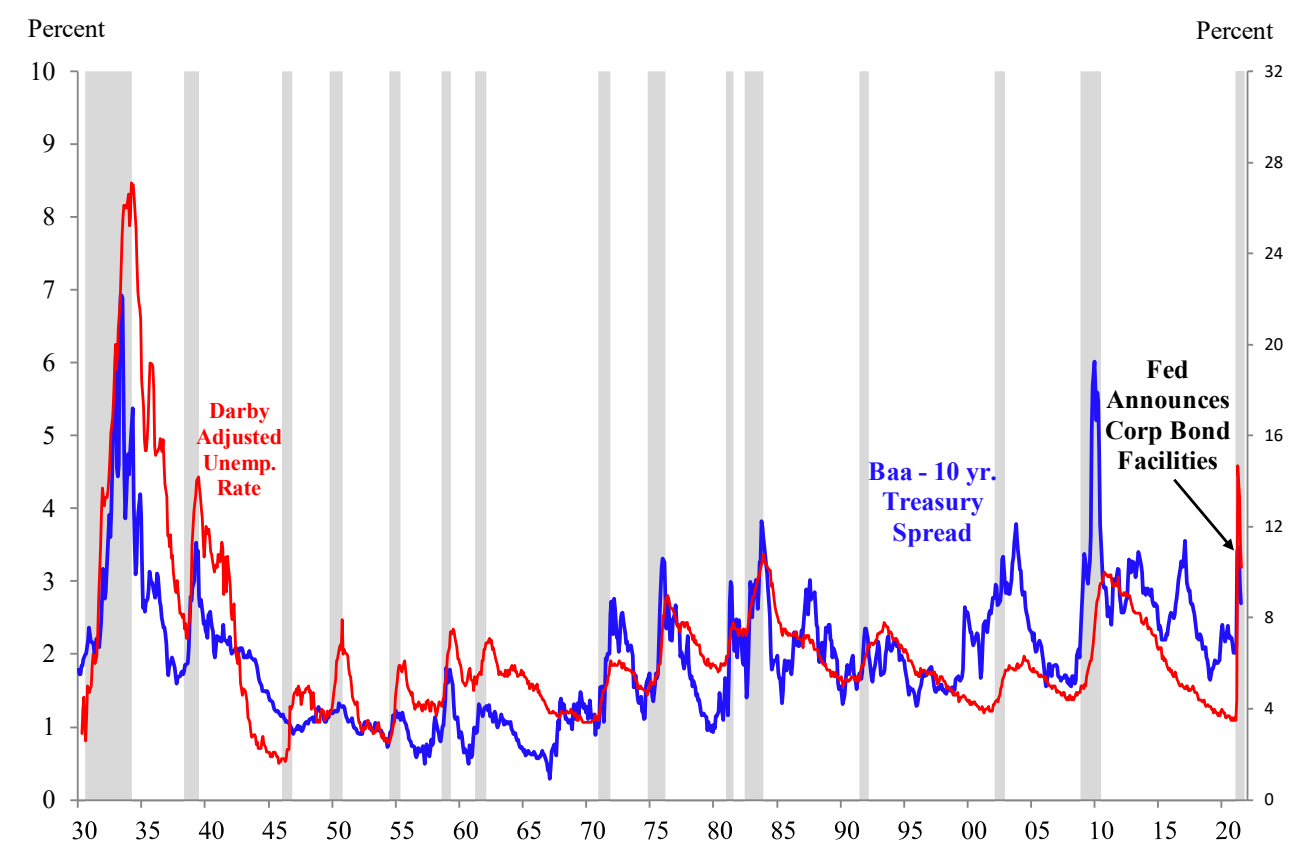

Figure 3: Since the Great Depression, Corporate-Treasury Bond Yield Spread Moves with the Unemployment Rate Until the Fed Announced its Corporate Bond Facilities (NBER recessions are shaded. Sources: Moody's, Federal Reserve, and authors' calculations)

$\left(U R^{2}\right)$, which is expected to be positively correlated with BaaTR.

That correlation, however, is affected by a major shift following the failure of the Penn Central railroad in April 1970 (PennCentral =1 since then, 0 before), which Jaffee (1975) also found significant. This failure marked a major shift in historical behavior that plausibly affected investor's assessment of the cyclical risk of investment-grade bonds because between 1941 and Penn-Central's failure in 1970, there were no defaults by investment-grade corporations (Jaffee (1975, p. 310), and Moody's (2007, p. 15), but 16 in the next 20 years. Further evidence of a quiet period between 1951 and June 1970, was that this period had only 17 defaults by speculative-rated corporations. It was followed by 342 defaults in the following 20 years. The period since Penn-

as long-term Treasury yields directly affect its slope and the base off which corporate and muni spreads are measured. In addition, the large QE purchases of long-term securities since 2008 affect the consistency of the yield curve over time. The post-2007 Fed balance sheet also limits the usefulness of the TED spread as the high excess reserves used to fund Fed bond holdings limits the ability of the TED spread to track more general market risk premia. 
Central's default is marked less by an upward level shift in the Baa spread and more by an increased amplitude of swings in the spread-i.e., an increased sensitivity of the spread to the business cycle (which is proxied by the squared unemployment rate in this study). This increased sensitivity persisted through the Great Moderation era (1984-2006) and past the Great Recession of 2007-09. While the increased amplitude of swings in the spread are somewhat correlated with defaults, it is unclear how much they reflect liquidity versus solvency risk.

Secular shifts in corporate debt risk can be tracked by either major and long-lasting changes in regulations and the conduct of monetary policy, or by time trends. The latter provides little insight and coefficient estimates on time trends can reflect omitted variable bias from not controlling for other factors. With respect to the former, we found two significant upshifts in the Baa corporate spread after WWII. The first is related to the conduct of monetary policy associated with the Treasury-Fed Accord of 1951. From the start of our sample up to the Accord, the long Treasury yield was constrained by 0 from below in the Great Depression era or by the pegging of the long-Treasury yield from 1942 to March 1951. As a result, there was less counter-cyclical monetary policy implying higher default risk before the Accord. Indeed, we find that a monetary policy regime shift dummy (PreAccord $=1$ before March 1951, 0 otherwise) is associated with a higher range of the spread-i.e., an upward shift in the constant in a model of the spread. We tested for other shifts related to monetary policy, but limits to the length of samples - such as the short period of the Gold Standard Convertibility (April 1929-December 1933) or money supply targeting (October 1979-October 1982) — hindered our ability to detect level shifts in BaaTR or shifts in its sensitivity to the unemployment rate. We did, however, find a large negative impact effect of the suspension of gold convertibility and the devaluation of the dollar in December 1933 on the change in BaaTR in our monthly model. 
The second major secular shift in BaaTR that we detected was an upshift in December 2000, when Congress approved the Commodity Futures Modernization Act (CFMA). As Bolton and Oehmke (2015) and Stout (2011) show, the CFMA exempts derivatives counterparties from the automatic stay in bankruptcy, enabling immediate collection from a defaulted counterparty, giving them a senior claim over most other bankruptcy claimants. The passage of CFMA was quickly followed by a surge in credit default swaps (Duca and Ling, 2020). By giving bankruptcy priority to derivatives (mainly credit default swaps), the CFMA lowered the priority of bond investors and made bonds riskier (see Bolton and Oehmke 2015). We find that a shift dummy $(C F M A=1$ since December 2000, $=0$ otherwise $)$ captures an upward level shift in the corporateTreasury yield spread. ${ }^{7}$

These considerations yield two specifications for econometrically modeling the equilibrium corporate Baa-Treasury spread, one using shift variables and the other a time trend:

$$
\begin{aligned}
& \text { BaaTR }_{\mathrm{t}}^{*}=\alpha_{0}+\alpha_{1} U R_{\mathrm{t}}^{2}+\alpha_{2} \text { PennCentral }_{\mathrm{t}} \mathrm{x} U R_{\mathrm{t}}^{2}+\alpha 3 \text { PreAccord }+\alpha_{4} C F M A_{\mathrm{t}} \\
& \text { BaaTR }_{\mathrm{t}}^{*}=\alpha_{0}+\alpha_{1} U R_{\mathrm{t}}{ }^{2}+\alpha_{5} \text { Trend }_{\mathrm{t}}
\end{aligned}
$$

where each coefficient $\alpha_{\mathrm{i}}$ has an expected positive sign. According to stationarity tests (Appendix B), BaaTR is not stationary at annual and monthly frequencies, with borderline results at a weekly frequency, while $U R$ is not stationary at a weekly frequency but is it is borderline whether $U R$ is stationary at annual and monthly frequencies. The first difference in each is stationary. Owing to their construction, the two level-shift variables, PreAccord and CFMA, are nonstationary.

Accordingly, we estimate (1) and (2) with monthly and annual data from 1929-early 2020 using a cointegration approach (Johanssen's (1995)) and for each, jointly estimate the long-run

\footnotetext{
${ }^{7}$ The CFMA era is also marked by greater international portfolio holdings of safe assets, such as long-term Treasuries, that may push down Treasury yields relative to corporate Baa yields.
} 
level and the short-run change. The latter first difference equation includes an error-correction term (the t-1 gap between the actual and equilibrium spread), lags of first differences of all the variables in the long-run equilibrium relationship and a vector $X$ of exogenous event shocks. The inclusion of the exogenous shock variables is needed to yield uncorrelated residuals in the first difference model and has little effect on the estimated coefficients of the long-run (equilibrium) relationship. For our preferred second model (eq. (1)), we estimate:

$$
\begin{aligned}
& \text { BaaTR }_{\mathrm{t}}=\alpha_{0}+\alpha_{1} U R_{\mathrm{t}}^{2}+\alpha_{2} \text { PennCentral }_{\mathrm{t}} \mathrm{x} U R_{\mathrm{t}}^{2}+\alpha 3 \text { PreAccord } \mathrm{t}+\alpha_{4} C F M A_{\mathrm{t}} \\
& \Delta \text { BaaTR }_{\mathrm{t}}=\beta_{0}+\beta_{1} E C_{\mathrm{t}-1}+\sum_{\mathrm{i}=1}^{\mathrm{n}} \beta_{2 \mathrm{i}} \Delta \text { BaaTR }_{\mathrm{t}-\mathrm{i}}+\sum_{\mathrm{i}=1}^{\mathrm{n}} \beta_{3 \mathrm{i}} \Delta U R_{\mathrm{t}-\mathrm{i}}{ }^{2}+\sum_{\mathrm{i}=1}^{\mathrm{n}_{1}} \beta_{4 \mathrm{i}} \Delta\left[\text { PennCentral }_{\mathrm{t}-\mathrm{x}} \mathrm{x} U R_{\mathrm{t}-\mathrm{i}}{ }^{2}\right] \\
& +\sum_{\mathrm{i}=1}^{\mathrm{n}_{1}} \beta_{5 i} \Delta \text { PreAccord }_{t-\mathrm{i}}+\sum_{\mathrm{i}=1}^{\mathrm{n}_{\mathrm{i}}} \beta_{6 \mathrm{i}} \Delta C F M A_{\mathrm{t}}+\Omega X_{\mathrm{t}}
\end{aligned}
$$

where $E C_{\mathrm{t}-1} \equiv$ BaaTR $\mathrm{t}-1-$ BaaTR $_{\mathrm{t}-1}^{*}$, lag lengths are chosen to minimize the SIC, $X$ is a vector of exogenous shock variables, $\Omega$ is a vector of coefficients for the $X$ vector of shocks and the estimation allows for time trends in each of the variables in the long-run equation but not a trend in the long-run relationship. (The corresponding model for eq. (2) omits the long-run shift variables and allows for a time trend in the cointegrating relationship). The estimated coefficient $\beta_{1}$ on the error-correction term is expected to be negative (so that the actual spread converges toward its equilibrium level), with the absolute magnitude implying the speed of error-correction for the frequency of the model data. Note that the model implicitly imposes an almost instantaneous reaction of the corporate bond yield to the long-term Treasury yield, reflecting the Treasury yield's role as a benchmark rate. The speed of error-correction (i.e., the speed at which the spread adjusts), really reflects lags in how the perceived relative risk and degree of risk aversion for Baa-rated corporate bonds adjust in response to the business cycle and the regime shifts. The latter involve 
the failure of the Penn Central railroad, the Treasury-Fed Accord and the CFMA-related shift in the bankruptcy priority and relative risk of Baa-rated corporate versus Treasury bonds.

Equations (3a) and (3b) comprise a baseline, long-sample model of the corporate-Treasury yield spread before the Fed announced in late March 2020 that it would intervene by buying mainly investment grade corporate bonds. If the Fed prevents the spread from rising past a threshold, its policy intervention breaks the normal equilibrium relationship. This can be easily be seen in Figures 1 and 3. Accordingly - and as discussed in more detail later on--for samples extending past February 2020, we adjust the baseline equation to allow for either a level shift in the equilibrium spread or a change in the impact of the unemployment rate on the spread.

\subsection{Modeling the Corporate-Treasury Yield Spread with Higher Frequency Data 1971-2020}

Given the short post-Covid sample, using higher frequency weekly data has the advantage of helping identify the effects of the pandemic and Fed interventions into the corporate bond market, but at the disadvantage of not spanning pre-1971 data. The weekly models have the advantages of using unemployment data that have not been spliced and avoid the need to control for regime shifts other than CFMA. Accordingly, the weekly specification simplifies to:

$$
\begin{aligned}
& \operatorname{BaaTR}_{\mathrm{t}}=\alpha_{0}+\alpha_{1} \mathrm{x} U R_{\mathrm{t}}^{2}+\alpha_{4} C F M A_{\mathrm{t}} \\
& \left.\Delta \text { BaaTR }_{\mathrm{t}}=\beta_{0}+\beta_{1} E C_{\mathrm{t}-1}+\sum_{\mathrm{i}=1}^{\mathrm{n}_{1}} \beta_{2 \mathrm{i}} \Delta B a a T R_{\mathrm{t}-\mathrm{i}}+\sum_{\mathrm{i}=1}^{\mathrm{n}_{\mathrm{i}}} \beta_{3 \mathrm{i}} \Delta\left(U R_{\mathrm{t}-\mathrm{i}}\right)^{2}\right]+\sum_{\mathrm{i}=1}^{\mathrm{n}_{1}} \beta_{4 \mathrm{i}} \Delta C F M A_{\mathrm{t}}+\Omega X_{\mathrm{t}}
\end{aligned}
$$

\section{Data and Variables}

Details on the unemployment rate and exogenous shock terms are described below as the dependent variable, BaaTR, and the CFMA variable were discussed earlier.

\subsection{Unemployment Rate}

The main cyclical variables used in this study are variants of the civilian unemployment rate for monthly and annual models, and or the weekly, insured unemployment rate from the initial 
claims for unemployment report. Annual unemployment data are from the Bureau of Labor Statistics (BLS) that the BLS derived from the monthly household survey since 1948 and from other Census surveys for earlier years. However, the readings from 1933 to 1943 are adjusted for time-varying employment in special Depression-era federal job-creation programs that were excluded from the calculation of the official unemployment rate. Adjustments use estimates from Darby (1976), who showed that official statistics from this period are not comparable with readings from other periods, and notably overstate unemployment in the mid- and late-1930s. As discussed in Appendix A, monthly readings on unemployment are adjusted building off Darby's estimates, but also for several breaks in data sources before 1948. Monthly data from the household survey spanning January 1948-present are spliced with 1940-47 data from an earlier Census survey and with 1929-39 data from the Conference Board.

For weekly models of the Baa-Treasury spread our main cyclical variable is based on the weekly, insured unemployment rate from the weekly initial claims report, available since 1971. By itself, the raw series has not consistently moved over time with the monthly unemployment rate, as stressed by Cleary, Kwok, and Valletta (2009). The major reason is that is the taxation of, and eligibility for, UI benefits has moved over time, as have the regional and unionized composition of employment which have affected the proclivity of the employed to file for benefits and count in the weekly unemployment rate series. To address this we multiply the seasonally adjusted weekly series by the centered, 12-week moving average of the ratio of the weekly unemployment rate to the monthly unemployment rate from the household survey. ${ }^{8}$ While the adjusted and unadjusted weekly unemployment rates are each significantly related to (cointegrated with) the Baa-Treasury spread and with the actual spread significantly error-correcting toward its

\footnotetext{
${ }^{8}$ The smoothing of the adjustment parameter limits noise in the weekly, and to a lesser extent in the monthly series.
} 
equilibrium value, the adjusted series yields short-run residuals that are not significantly correlated in contrast to residuals from a model of the unadjusted series.

\subsection{Monthly Exogenous, Shock Variables}

Aside from the failure of Penn-Central in 1971 which enters the models interacted with the unemployment rate, there are five major monthly shocks that are added to the corporate bond market. Of these, four occur during the Great Depression and three of these reflect temporary, but large effects of bank failures and crises on the Baa-Treasury spread in an era predating deposit insurance and an aggressive lender of last resort approach by the Fed. One shock is the failure of the Bank of the U.S. in December 1931. This was the largest bank failure in the U.S. at that time and triggered a temporary surge followed by a fall back in the Baa-Treasury spread. To control for this outsized double-event, we include a dummy variable, USBankFail, which equals 1 in December 1931, -1 in January 1932 and 0, otherwise.

Another similar variable, $Q E 1932$, equals 1 in April 1932 when the Fed began conducting a quantitative easing-like program of purchasing long-term Treasuries, which notably pushed down long-term Treasury rates (Bordo and Sinha, forthcoming), thereby widening the BaaTR spread. Otherwise, this variable equals 0, except for equaling -1 in August 1932, just after the Fed announced a cessation to this QE precursor, which let long-term Treasury rates rise, narrowing the spread. The third Great Depression era bank crisis dummy controls for the banking crisis of early 1933 (BkCrisis33), which triggered a jump in the Baa-Treasury spread in March 1933 that did not

reverse until May 1933, just after solvent banks were publicly certified during the Bank Holiday of 1933. To control for this third temporary spike, the dummy variable BkCrisis33 is included which equals 1 in March 1933,-1 in May 1933, and zero otherwise. The fourth Great Depression variable controls for the sharp decline in the Baa-Treasury spread in December 1933 (DGold34= 
1 in January 1934, 0 otherwise), when the U.S. devalued the dollar relative to gold, signaling that monetary policy would be less constrained by the gold standard and better able to have a countercyclical effect, thereby reducing corporate bond default risk. ${ }^{9}$ To control for the outsized effect on corporate bond spreads of Lehman's failure in late September 2008, we include a fifth and last shock variable is dummy equal to 1 in October 2008 , shortly after, and 0 , otherwise. ${ }^{10}$

\subsection{Annual Shock Variables}

Annual models include three shock terms. The first is a dummy (BankFail3132 $=1$ in 1931 and 1932, and 0 otherwise) to control for the unexpected onset of large bank failures in an era lacking deposit insurance and a sound lender-of-last resort strategy by the Federal Reserve (e.g., see Bordo (2014, p. 130). The second, Gold1934, is a dummy (= 1 in 1934, and 0 otherwise) to control for the devaluation of dollar in 1934 and end of convertibility, that enhanced the ability of counter-cyclical monetary policy and lowered corporate default risk. The last control, Lehman, is a dummy equal to 1 only in 2008 ( 0 , otherwise) to control for the outsized jump in the BaaTreasury spread during the year of Lehman's failure that also included the federally assisted sale of Bear Stearns and the full onset of the Global Financial Crisis.

\subsection{Weekly Shock Variables}

In parallel with the monthly models, the set of exogenous variables for the weekly, post1970 model includes a dummy for the failure of Lehman (DLehman $=1$ for the week of September 19 and 0 , otherwise). However, three other short-run controls need to be added for the short-run model to avoid having serially correlated errors. Two are dummies for the 1987 stock market crash

\footnotetext{
${ }^{9}$ The negative sign on DGold34 that we estimate suggests that this countercyclical factor appears to have offset a potential countervailing positive effect on the spread from increased uncertainty about how much bonds were worth following the abrogation of gold clauses in debt contracts when the US left the gold standard in 1933. This was very controversial at the time and was not resolved until a Supreme court decision in 1935 (see Edwards. 2018).

${ }^{10}$ Several potential geo-political shocks that could alter the spread proved insignificant, such as dummies for the start of WWII in Europe, the fall of France in June 1940, and the December 1941 attack on Pearl Harbor. Other dummies for the Fed's raising of reserve requirements in 1936 and 1937 were insignificant.
} 
(StockCrash87 =1 in the week of October 23, 1987 and 0, otherwise) and the September 2001 terrorist attacks ( $D 911=1$ in the week of September 13, 2001, and 0, otherwise). The estimated coefficients are expected to be positive reflecting likely increases in corporate default and liquidity risk during these two crises. The third shock variable is for Standard and Poors' 2011 downgrading of U.S. Treasury debt from Aaa to Aa (USDGrade $=1$ in the week of August 12, 2011, and 0, otherwise). Since the unexpected downgrade would likely push up yields on Treasuries relative to those on other debt securities, the estimated coefficient on USDGrade is expected to be negative. The exclusion of the complete set of exogenous shocks results in a long-run model yielding a unique and significant cointegrating vector having similar coefficients and a short-run model with a similar estimated and significant speed of error-correction. The only notable difference is that the errors are serially correlated when these shock variables are omitted.

\section{Estimation Results}

Models of the corporate Baa-Treasury spread are estimated using data spanning two sample periods: 1929 - 2020 for monthly and annual linear models and $1971-2020$ for weekly and monthly nonlinear models. The advantage of the long sample is that it spans the Great Depression. The shorter sample, weekly models have more observations to assess the impact of the Covid pandemic and the Fed interventions into the bond markets. In the models highlighted in the text, the unemployment rate terms are set to zero after the Fed announced bond market interventions, which essentially shutdown the impact of unemployment on the spread.

\subsection{Monthly and Annual 1929-early 2020 before the Fed Corporate Bond Market Interventions}

Results from estimating monthly and annual models with data starting in 1929 are reported in Table 2. These models include the PennCentral shift in the cyclicality of the spread and the Treasury-Fed Accord and CFMA shift level shift terms in the long-run model, and the set of shock 
terms in the $X$ vectors described in Section 3.2. The Schwartz Information Criterion selected lag lengths on lagged first differences in the short-run model of 6 for the monthly model ( $1 / 2$ year) and one for the annual model. Annual Models 1 and 2 exclude and include annual shock variables. Monthly Models 3 and 4 parallel Models 1 and 2 over a pre-Covid sample (Nov. 1929 - Feb. 2020), while Models 5 and 6 do so over a sample spanning the early Covid downturn (Nov. 1929-July 2020 ) with the distinction that they both zero out the unemployment rate channel after the Fed announced corporate bond interventions (discussed in Sub-Section 6.4). In all cases, significant and unique cointegrating relationships are found. In the models with full controls, the shock variables have the expected signs and are generally significant and including these shock terms is needed for the residuals of short-run models to avoid being serially correlated. On these grounds, the models with the shock terms (Models 2, 4, and 6) are preferred. Of these, for the pre-Covid samples the annual (Model 2) and monthly (Model 4) models have similar estimated long-run relationships and adjustment speeds:

$$
\begin{aligned}
& \text { BaaTR }_{\mathrm{t}}=1.070+0.004 \times U R_{\mathrm{t}}^{2 * *}+0.018\left[\text { PennCentral } \mathrm{x} U R_{\mathrm{t}}^{2}\right]^{* *} \quad \text { (Annual Model) } \\
& (0.001) \quad(0.003) \\
& +0.532 \text { PreAccord }_{\mathrm{t}}^{* *}+0.628 \text { CFMA }_{\mathrm{t}}^{* *} \quad \text { Speed of adjustment: } 0.45 / \text { year } \\
& \text { (0.171) (0.143) } \\
& \begin{aligned}
\text { BaaTR }_{\mathrm{t}}= & 1.042+0.005 \times \text { UR }_{\mathrm{t}}^{2 * *}+0.014[\text { PennCentral } \\
& \left.(0.001) \quad U R_{\mathrm{t}}^{2}\right]^{* *} \quad \text { (Monthly Model) } \\
& \left.+0.423 \text { PreAccord }_{\mathrm{t}}^{* *}+0.002\right)
\end{aligned}
\end{aligned}
$$

where absolute standard errors are in parentheses, ${ }^{*}\left({ }^{* *}\right)$ denotes significant at the 95 (99) percent confidence level, the annual model is estimated using data from 1929-2019, and the monthly model is estimated with data from April 1929 to February 2020.

In each model in Table 2, the long-run coefficients are all significant with the expected signs. The positive coefficients on the Pre-Treasury Fed Accord and CFMA long-run effects are 
notable and imply a need to account for regime shifts affecting long-run spreads. The coefficient and standard error on the squared unemployment rate interacted with the Penn-Central level shift dummy indicate a statistically and economically significant increase in the cyclicality of the BaaTreasury spread since the failure of Penn-Central. This supports the view that this bankruptcy spurred a reassessment of the cyclical risk of investment-grade bonds, which had not seen a default in nearly 20 years prior and that the default was the largest bankruptcy in U.S. history at its time.

Of the even-numbered models having short-run shock terms, the corrected $\mathrm{R}^{2}$ 's for the short-run model portions range between 0.44 and 0.48 , which are reasonable for models of the first-difference of a spread. In addition, the error-correction terms are significant with the expected negative sign and imply sensible speeds at which the Baa-Treasury spread adjusts to its long-run equilibrium. In particular, the estimated coefficients from models with shock terms imply that 44 to 48 percent of the gap between the actual and equilibrium level of the corporate-Treasury spread is corrected in a year. As expected, the dummies for the failure of the Bank of the U.S., the Fed's short-lived QE experiment in 1932, and Lehman's demise were positive and significant, while the December 1933 change in the gold standard had a significantly negative effect.

\subsection{Common 1971-Feb. 2020 Sample before the Fed Corporate Bond Market Interventions}

Results from estimating monthly and weekly models with post-1970 samples are reported in Table 3. Owing to their later sample start, these models omit the Great Depression, TreasuryFed Accord, and PennCentral variables. Of the three weekly models, Models 1 and 2 exclude and include a set of weekly shock variables over a pre-Covid sample, while Model 3 includes that set plus some Covid controls and shuts down the unemployment channel after the Fed announced its corporate bond interventions discussed later. The set of exogenous dummy shock terms include controls for the stock market crash of 1987 (DStock87), the September 2001 terrorist attack 
(D911), the failure of Lehman (DLehman), and Standard and Poor's 2011 debt ceiling-related downgrade of U.S. Treasuries (DUSDGrade). Paralleling the weekly models, three monthly models (4-6) are reported in Table 3, the first of which (Model 4) omits the controls over a preCovid sample. Model 5 is also estimated over this sample and to Model 4 only has the Lehman failure dummy among its shock variables as this is the only post-1971 shock from the 1929-2020 monthly model. Model 6 adds Covid controls to Model 5, shuts down the unemployment rate channel after the Fed's announced its corporate bond programs, and is estimated through July 2020. The Schwartz Information Criterion selected lag lengths on lagged first differences in the short-run model of 6 for the monthly model and 12 for the weekly model.

For both data frequencies, we identify a significant and unique long-run cointegrating relationship in each model and the corresponding short-run models have uncorrelated residuals. For the pre-Covid sample models with short-run controls (Models 2 and 5), estimated long-run coefficients and speeds of adjustment error-correction are significant and similar:

$$
\begin{array}{ccc}
\text { BaaTR }_{\mathrm{t}}=1.469+0.0121 U R_{\mathrm{t}}{ }^{* *}+0.6554 C F M A_{\mathrm{t}}{ }^{* *} & \text { Speed of adjustment: } 0.086 / \text { mon. } \\
(0.0034) & (0.1432) & \approx 66 \% \text { per year (Monthly Model } 5) \\
\text { BaaTR }_{\mathrm{t}}=1.368+0.0136 U R^{2}{ }^{* *}+0.7381 C F M A_{\mathrm{t}}^{* *} & \text { Speed of adjustment: } 0.073 / \text { month } \\
(0.0031) & (0.1383) & \approx 56 \% \text { per year (Weekly Model 2) }
\end{array}
$$

For the two models with short-run controls that are estimated over the pre-Covid sample, the short-run weekly model (Model 2) of the first difference of the spread does not fit as well as the monthly model (Model 5), having a corrected $\mathrm{R}^{2}$ of 0.11 versus 0.27 for the monthly model. This smaller fit likely reflects the greater noise in the weekly spread, consistent with the view that corporate bonds are not as thickly traded as are Treasuries. Nevertheless, the error-correction terms are significant with the expected negative sign and imply sensible speeds at which the Baa- 
Treasury spread adjusts to its long-run equilibrium. In particular, the estimated coefficient from the monthly model implies that 66 percent of the gap between the actual and equilibrium level of the corporate-Treasury spread is corrected in nearly one year, while the estimated coefficient from the weekly model implies that about 56 percent of the gap is corrected within a year. As expected for short-run shock terms, the estimated coefficients on DLehman, StockCrash87, and D911 are significant and positive while that for USDGrade is negative and significant.

\subsection{Pre-Covid Long-Run Trends in the Baa-Treasury Spread}

Before the Covid pandemic hit the U.S., the estimated equilibrium generally trends with the actual spread, with upward spikes during periods of heightened risk that are hard to predict or forecast. This is illustrated in Figure 4, which plots the actual monthly spread with the predicted values from the long- and short-sample monthly models. Notice how much the equilibrium exceeds the actual if its estimated coefficients are applied to the post-February 2020 period, which is more easily seen in Figure 5, which plots data since 2000. The model using data back to the Great Depression indicates that pre-Covid patterns implied a peak of 6.0 percent in the spread with a less elevated peak of 4.7 percent using the post-April 1971 monthly model. These readings are 2.5 and 1.2 percentage points above the actual peak in April 2020, respectively, and provide a loose gauge of the range of effects of the Fed's announced interventions in the corporate bond market - measured by the more normal cyclical response of spreads but lacking a gauge or other, more liquidity, effects of the pandemic. Similar exercises using the weekly model yield an implied equilibrium path (not shown) very close to that implied by the monthly model estimated over the same time span (May 1971 to February 2020) shown by the red lines in Figures 3 and 4. This exercise presumes that the pre-Covid patterns would have prevailed absent the Fed's announced interventions into the corporate bond market. As shown in Figure 6, this assumption is supported by the patterns in higher frequency weekly data, which show the Baa-Treasury bond spread 


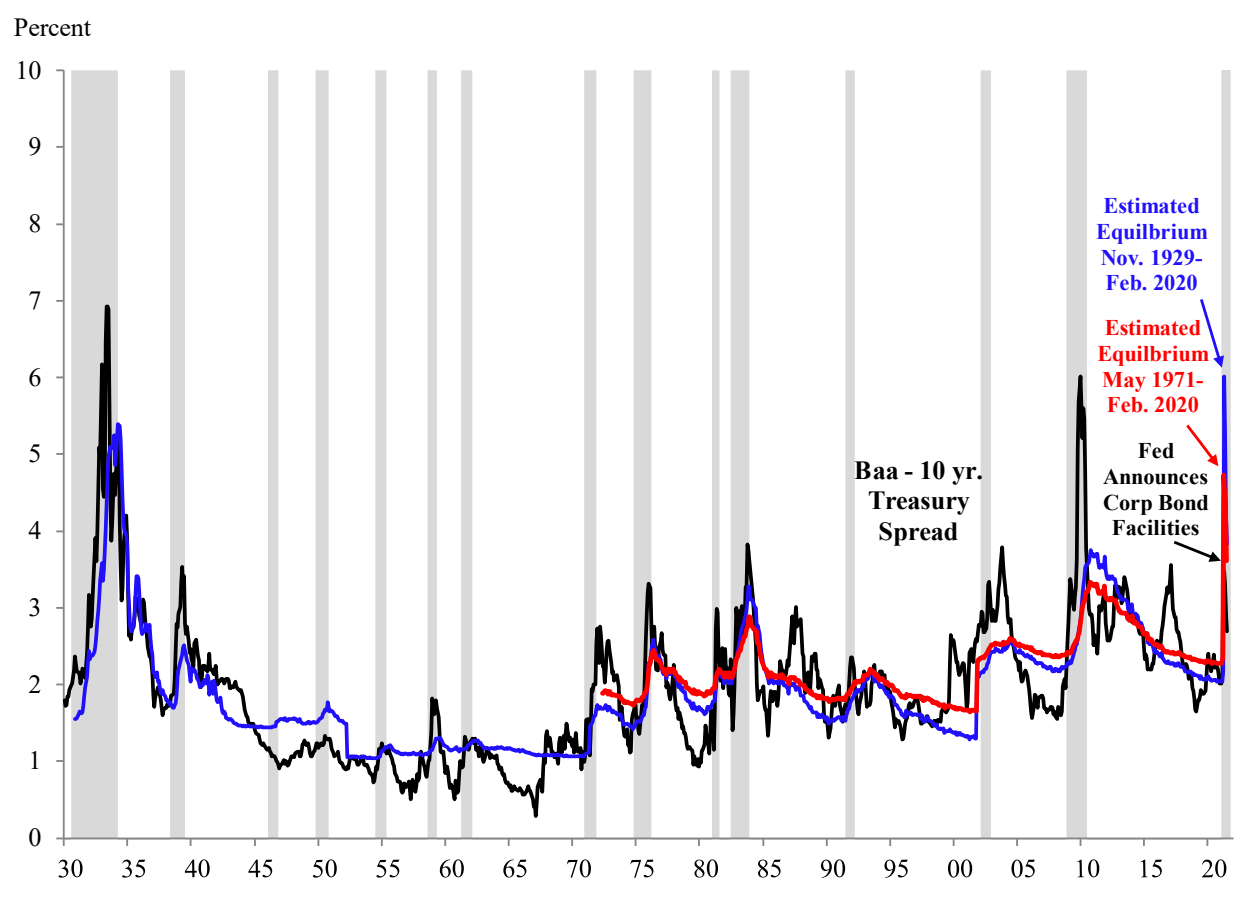

Figure 4: Equilibrium Spreads Track Actual Baa-Treasury Spreads until March 2020 (NBER recessions are shaded. Sources: BLS, NBER Macro-History Database, Moody's, Federal Reserve, and authors' calculations)

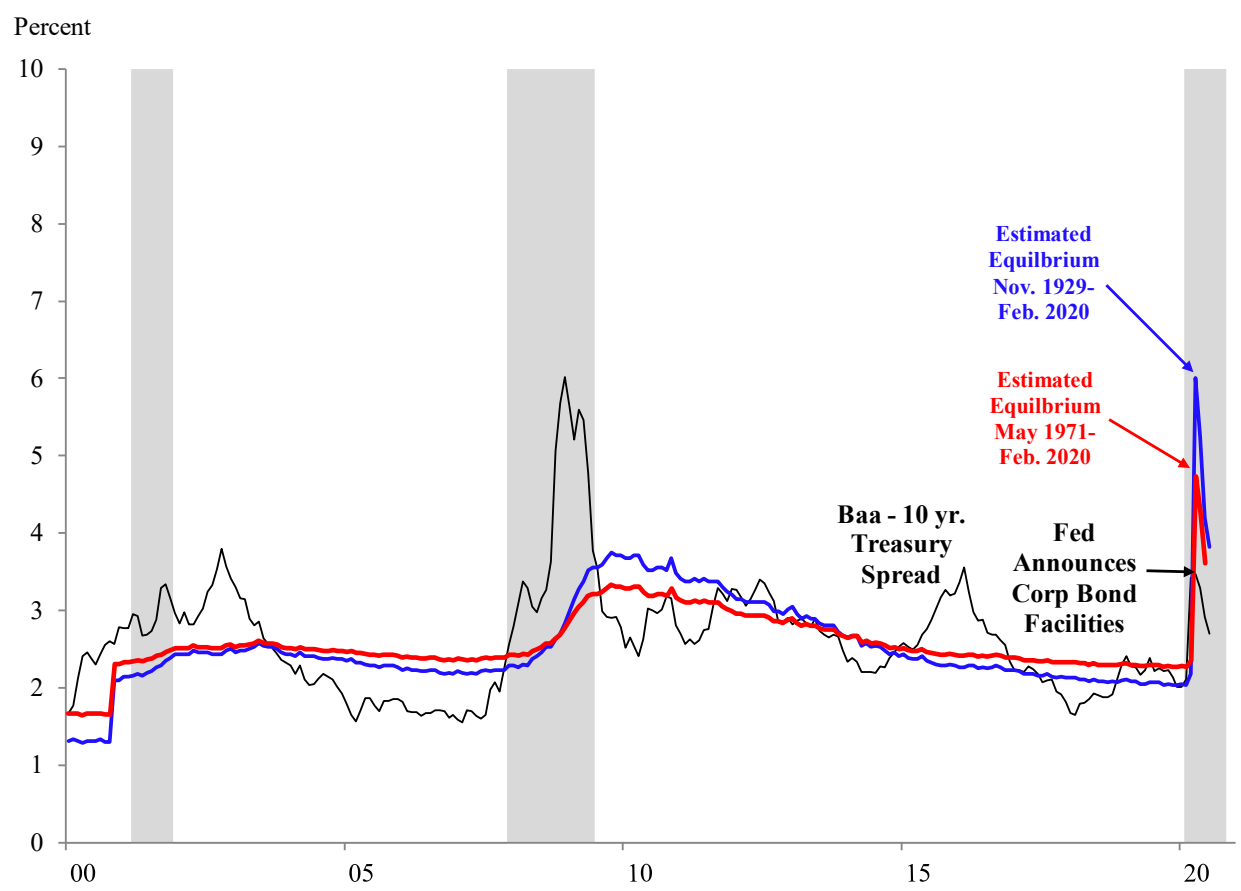

Figure 5: Pre-Covid Relationships Imply a Sharper Jump in the Corporate-Treasury Bond Yield Spread Than Was Seen Since March 2020 (NBER recessions are shaded. Sources: BLS, NBER Macro-History Database, Moody's, Federal Reserve, and authors' calculations) 


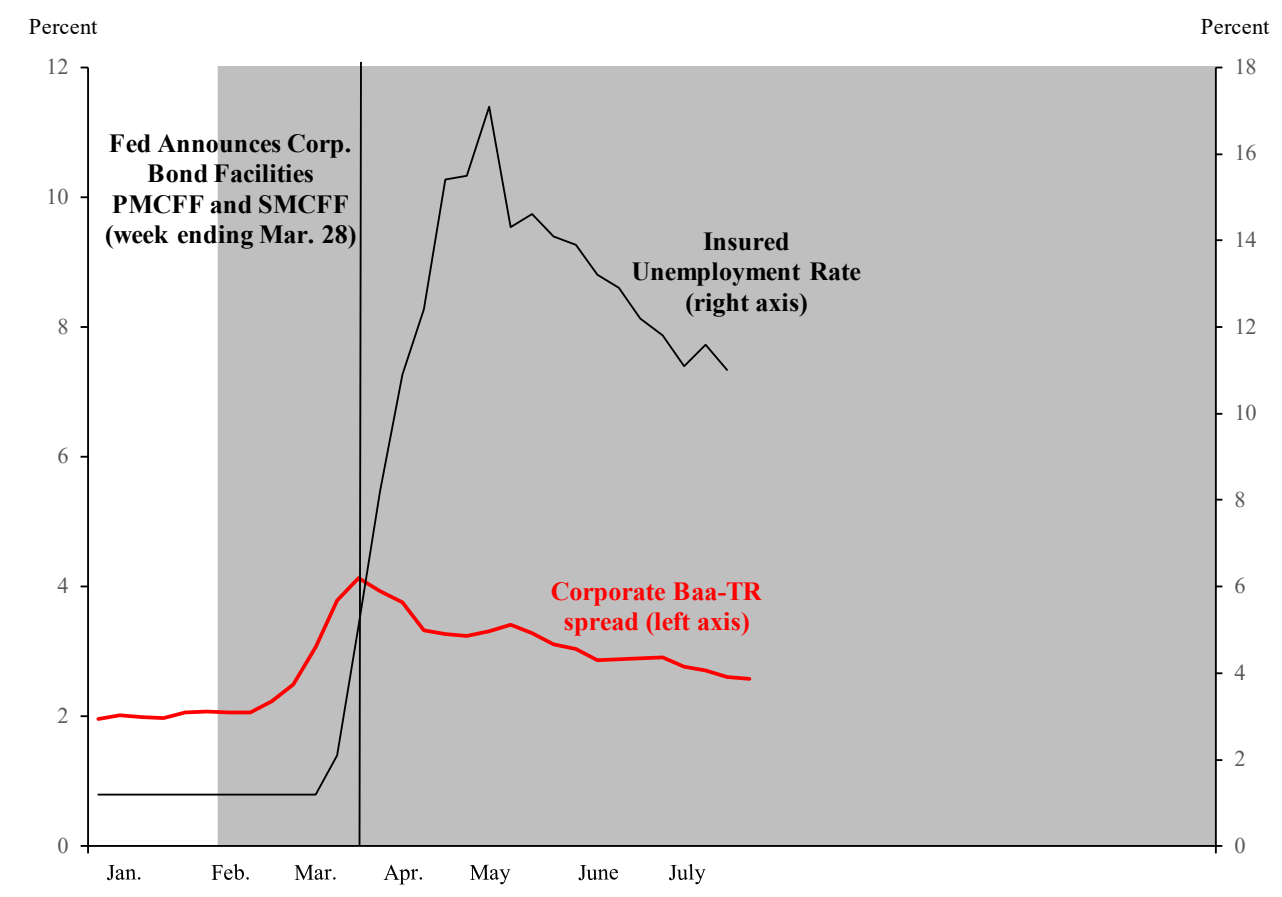

Figure 6: In 2020, Yield Spreads Rise with Insured Unemployment Rate Until the Fed Announced its Corporate Bond Facilities

(NBER recessions are shaded. Sources: BLS, NBER Macro-History Database, Moody's, Federal Reserve, and authors' calculations)

moving in line with the weekly insured unemployment rates in February and March 2020, up until the Fed's announcement of corporate bond purchases.

\subsection{Assessing Covid and Fed Bond Market Intervention Effects on the Bond Spread}

Figures 1, 2, and 3 strongly suggest that the Fed's announced intervention into the corporate bond market had a pronounced effect on the corporate-Treasury spread, essentially altering the relationship between the unemployment rate and the spread. When the monthly and weekly models are estimated over samples through July 2020, the estimated coefficients on the unemployment rate fall and lose significance. Moreover, models with no Covid and Fed intervention adjustments are unable to yield both a significant and unique long-run relationship and serially uncorrelated residuals in the short-run models of the change in the spread. Simply adding a Covid level shift term or a Fed bond market-intervention term to the long-run relationship 
is not feasible as the lag length needed to estimate the model exceeds or is close to exceeding the number of observations since these events.

To adjust the framework to gauge the effects of the pandemic and the Fed interventions, we make two changes when estimating the models through the end of July 2020. First, we shut down the feedback from the unemployment rate to the spread after the Fed's announced intervention (which is generally the intent of the intervention). To do this in the long-sample monthly model, we multiply both of the squared unemployment variables by a discrete interaction dummy (FedxBond) that equals 1 before March 2020, zero starting in April 2020 and by $1 / 4$ for March 2020 (reflecting the March $23^{\text {th }}$ timing of the Fed's announcement). In the simpler, post1970 monthly model, we multiply the squared unemployment rate by the same discrete variable. For the post-1970 weekly model, we multiply the squared unemployment rate by a weekly dummy that equals one until the week ending March 21, 2020, 1/2 the next week, and 0 thereafter. In other models, we made analogous adjustments based on the May $12^{\text {th }}$ start of Fed purchases of corporate bond ETFs and found the fit of these models were less than the announcement-based models.

The second change made to estimate the impacts of Covid and Fed corporate bond facilities was to add Covid-shock dummy variables. In the monthly model, we add a Covid dummy variable equal to 1 since March 2020, and two lags of its first difference (essentially one-time shock variables for April and May). In the weekly model, add a Covid dummy variable equal to 1 since the week ending March 13 plus the current and 12 lags of its first difference (essentially one-time shock variables for April and May). Both adjustments essentially allow the pandemic to have an effect ahead of its effect on the unemployment rate (which tends to lag a little). In an error correction framework, a short-run shock's effect will partially wear off each week, which, as will be shown later, generally fits the time series movement of the spread. With these adjustments, the 
models continue to yield significant and unique long-run relationships that have similar coefficients to the pre-Covid estimates shown earlier (see Tables 2-3), with sensible short-run models that display significant error-correction and do not have serially correlated residuals. While these adjustments are far from ideal—which would require more observations that are not yet available - they do provide some perspective on the spread during the era marked by the Covid pandemic and Fed interventions in the corporate bond market. ${ }^{11}$ In particular, the timing of the Fed intervention and the importance of adjusting the baseline models to enable them to work well post-Covid imply that the Fed's intervention has fundamentally altered the behavior of the BaaTreasury spread.

The models with the adjustments each yield a long-run estimated equilibrium spread, with the Covid dummies essentially controlling for liquidity effects from the pandemic. Using the full sample (through the end of July 2020) coefficients on the squared unemployment terms, Figures 6 and 7 plot the implied, cyclical effect that the announced Fed corporate bond interventions had on the Baa-Treasury spread for the two monthly and the weekly models, respectively. From the monthly models, the peak effects are in April, reaching 3.9 percent in the model using data back to the Great Depression versus a smaller 2.2 peak effect from the monthly model estimated since May 1971. On the one hand, the longer sample could yield more accurate estimates than the shortsample estimation if the splicing of the unemployment rate is accurate and if the adjustments to the econometric framework adequately address pre-1971 regime shifts over the 1929-2020 sample period. On the other hand, the longer sample model could suffer from possible measurement error

\footnotetext{
${ }^{11}$ The timing effects of the Fed intervention that are embodied in model 6 accord with daily data on the Baa-Treasury spread (available since 1986) in that the daily spread rises sharply in early and mid-March, and then peaks on March 23, when the Fed announced the corporate facilities. In related work in progress, we find a similar pattern for spread between yields on Baa-rated municipal and the 10-year Treasury bond, except that the muni spread peaks on April 9, when the Fed announced it would buy municipal bonds by creating its Municipal Liquidity Facility.
} 
from splicing unemployment rate series or misspecification from omitting other structural differences across the earlier and later parts of the sample. It is unclear which model is more accurate. Accordingly, considering and monitoring the accuracy of both models will likely be informative, and the two lines in Figure 7 provide upper and lower estimates of the cyclical effect of the Fed's announcement of new corporate bond facilities. Estimates from the preferred monthly model (model 6, Table 3) imply a peak effect of 3.9 percent occurring in the second business week in May with the effect tailing off to about 1.7 percent at the end of July 2020. It is unclear, however, how much these estimates track the effects from shifts in liquidity versus solvency risk. With these qualifications in mind, these estimated effects in Figures 7 and 8 are notable and seem reasonable — being on the order of those calculated by Duca and Murphy (2013) for what such a facility could have done in the Great Recession, with an estimated impact of about 1 full percentage point on real GDP. One difference is that the Duca and Murphy (2013) estimates include implied default and liquidity effects by using the gap between the actual spread and a specified cap.

\subsection{Gauging Fed Bond Market Intervention Effects on the Macroeconomy}

To examine the impact of the Fed's corporate bond programs on the real macro-economy, we examine two types of evidence. First, we use the estimated impact of the programs on bond spreads with the effect of bond spreads on the output gap in the recently revised Federal Reserve Board Model of the U.S. economy (FRBUS) described by LaForte (2018). In the FRBUS model, the equity risk premium is mainly driven by movements in the spread between yields on S\&P BBrated corporate and the 10-year Treasury bond. This spread is equivalent to our Moody's based Baa-Treasury spread. ${ }^{12}$ Converting the monthly model estimates plotted in Figure 6 into quarterly averages, the announced interventions lowered the Baa-Treasury spread by 2.99 and 1.93

\footnotetext{
12 The FRBUS system models the bond risk spread mainly as a function of the output gap and random shocks, the former effects being similar to our modeling the Baa-Treasury spread as driven by the unemployment rate.
} 
percentage points in 2020:q2 using the longer and shorter samples, respectively.

In the FRBUS model, the spread between yields on investment-grade corporate and 10year Treasury bond yields affects the real economy via three main channels. First, a higher spread depresses stock prices by pushing up the equity risk premium. In addition, a higher spread raises the user cost of capital, thereby depressing business investment, and pushes up spreads of home mortgage over long-term Treasury interest rates, thereby lowering residential investment.

To assess the impact of the corporate bond facilities on real GDP, we ran simulations of the FRBUS model under the assumptions of an inertial Taylor Rule and that the effective zero lower bound on the federal funds rate would be binding throughout the forecast period. Using publicly available inputs, these assumptions yield a baseline. Alternative assumptions for the BBB -10-year Treasury spread are generated by assuming the counterfactual that the Fed corporate bond programs were not implemented. Each of the three estimated models imply different monthly paths for the equilibrium spread, which for simplicity we assume would have immediately affected the actual spread absent the PMCCF and SMCCF. The implies quarterly average higher levels of the spread for 2020:q1 and 2002:q2, which are augmented with a 2020:q3 level equal to the July 2020 equilibrium spread that is assumed to persist throughout the forecast period.

This exercise produces noticeably lower paths for real GDP than the baseline that translate into more negative real output gaps (scaled by potential real GDP), which are reported in Table 4. After four quarters (2021:q2), real GDP is 0.6 to 0.9 percentage points lower, with the largest effect in the monthly model estimated from 1929 to 2020 and the smallest effect in the monthly model estimated from 1971-2020, with the ranking of the relative GDP effects matching the relative effects on the Baa-Treasury interest rate spread. After 6 quarters, the magnitudes grow, ranging from 1.1 to 1.7 percentage points, with an even larger range between 1.6 to 2.5 p.p. after 8 quarters. 


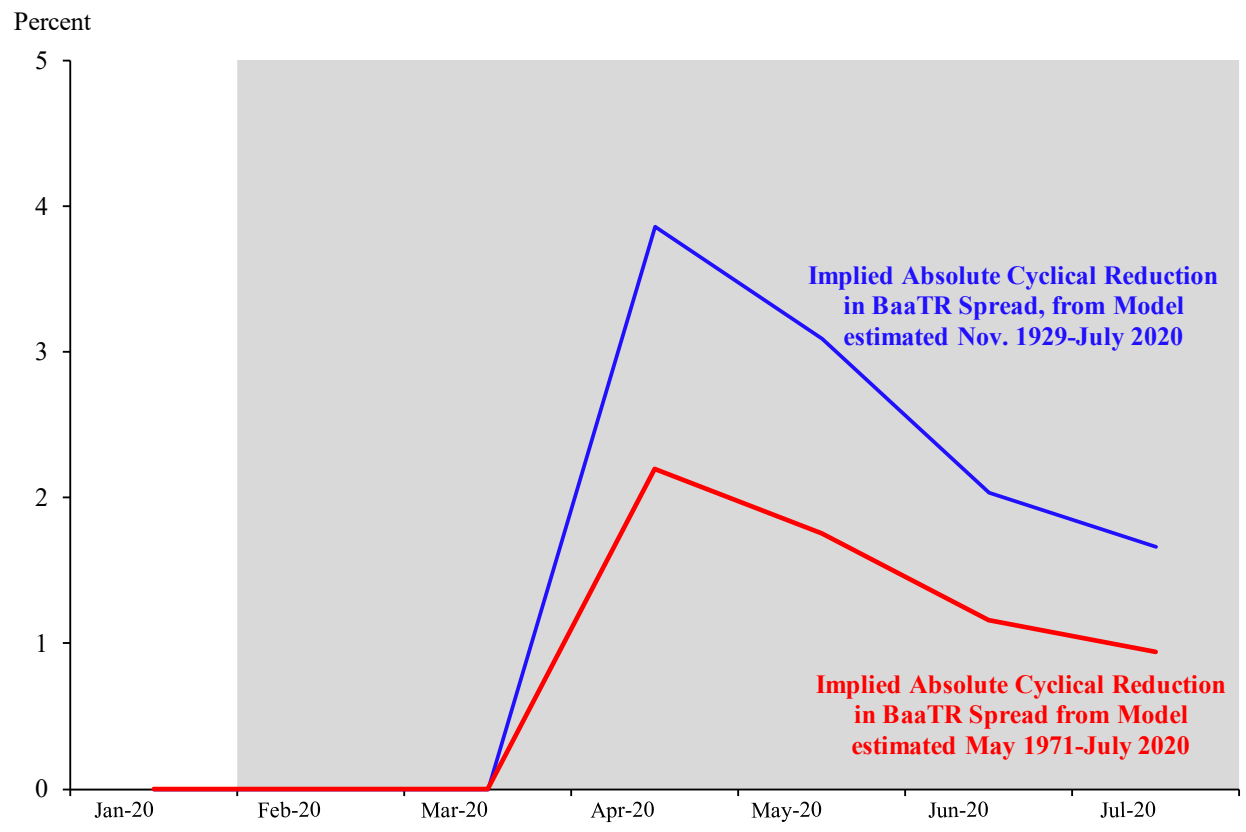

Figure 7: Monthly Model Estimates Suggest a Substantial Cyclical Effect of the Announced Fed Intervention on the Corporate-Treasury Spread

(NBER recessions are shaded. Sources: Moody's, Federal Reserve, and authors' calculations)

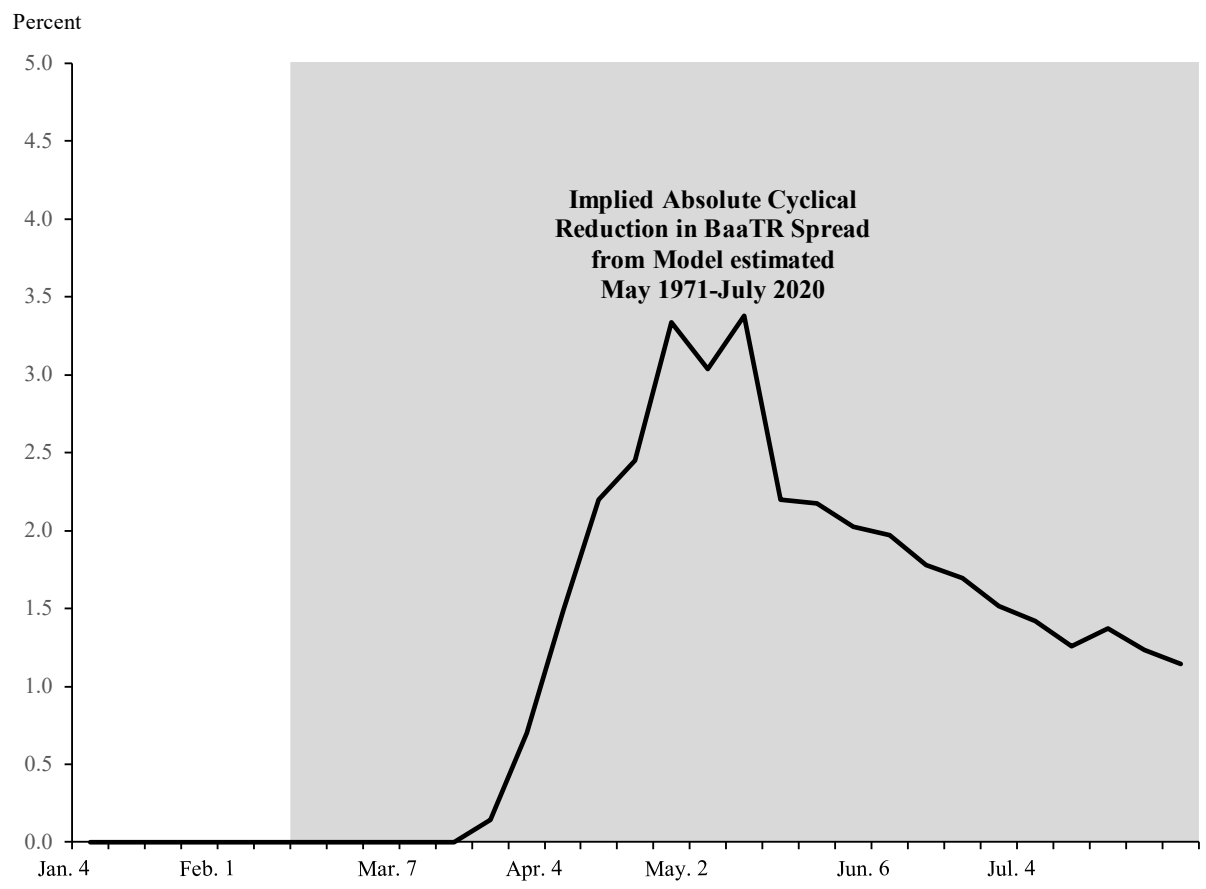

Figure 8: Weekly Model Estimates Suggest a Substantial Cyclical Effect of the Announced Fed Intervention on the Corporate-Treasury Spread

(NBER recessions are shaded. Sources: Moody's, Federal Reserve, and authors' calculations) 


\begin{tabular}{|c|c|c|c|}
\hline Model $\backslash$ Forecast Period & 4 quarters & 6 quarters & 8 quarters \\
\hline Monthly, 1929-2020 & -0.9 & -1.7 & $-2,5$ \\
\hline Monthly, 1971-2020 & -0.6 & -1.1 & -1.6 \\
\hline Weekly, 1971-2020 & -0.8 & -1.4 & -2.1 \\
\hline
\end{tabular}

\section{Table 4: Counterfactual Simulations of Real GDP Absent Fed Corporate Bond Programs (Source: authors' calculations and simulations using the FRBUS model)}

One concern with these estimates and calculations is that default risk is endogenous to the cycle, raising doubts about using corporate spreads. To address this general concern with bond spreads, Gilchrist and Zakrajsek (2012) use microdata and estimates to extract the impact of default risk on investment-grade spreads, yielding their estimates of an excess bond premium (EBP). Note that the raw, investment grade spread (the "GZ spread) from which they derive the EBP moves very closely with the Baa-Treasury spread used in our study over a common 1973-2020 sample. The authors demonstrate the leading indicator properties of the EBP for real GDP, and later in a study with Favara, et al. (2018), they show how the EBP is useful for forecasting recessions. According to their 2012 study, a 20-basis point rise in the EBP (about a one-standard deviation shock) lowers real GDP by about 0.4 percent after four and eight quarters. Note that these estimates include the cushioning effects of a normal, countercyclical monetary policy response.

To draw upon their findings, we empirically model the EBP (available Jan. 1973 - present) using the posted monthly updates to it that are described in Favara, et al (2016). One difference with the Baa-Treasury spread is that the EBP is stationary. Accordingly, we adjust our framework to model the EBP as a function of changes in the unemployment rate, which are also stationary. Using the SIC for lag selection on the EBP, we estimated the EBP on the month t-2 change in the unemployment rate and on t-1 to t-5 lags of EBP over the sample July 1973 - February 2020. This model minimized the SIC across different lags of the EBP and yielded clean model residuals. 
In line with our earlier estimates of the level of the Baa-Treasury spread, the t-2 change in the unemployment rate is positively and significantly related to the excess bond premium as indicated in model 1 in Table 5. This finding accords with the results for modeling the level of the spread as a positive function of the level of the unemployment rate. It is also consistent with the FRBUS model, which specifies the BBB-Treasury yield spread as a negative function of the output gap-which is negatively related to the unemployment rate, implying a positive relationship between unemployment and the spread. Model 2 re-estimates Model 1 over the full sample and finds the coefficient on the unemployment rate falls by over 70 percent in magnitude and becomes insignificant without any control for the Fed's corporate bond program or the March 2020 onset of the Covid pandemic in the U.S. Model 3 re-estimates Model 2 adding a single Covid-pandemic impact dummy (DCovid = 1 in March 2020 and 0, otherwise), and the unemployment rate is insignificant as in Model 2. Model 4 is also estimated over the full sample but follows our earlier level specifications in interacting the unemployment rate with the regime dummy FedxBond and includes a Covid impact dummy. The $\mathrm{t}-2$ change in the unemployment returns to being significant with a coefficient near that of Model 1. This pattern of results supports the view that the announcement of the Fed's corporate bond interventions stopped the reinforcing feedback effects of unemployment on corporate bond risk premia.

Models 1 and 4 imply that the 8.8 percentage point rise in unemployment between 2020:q1 and 2020:q2 would have boosted the EBP by about 1.15 (0.132 coefficient x 8.8) from 2021:q1 levels in the absence of the Fed intervention. Applying Gilchrist and Zakrajsek (2012) estimates that a 0.2 rise in EBP lowers real GDP by a little more than 0.4 percent after four quarters implies that the announcement of the Fed corporate bond program prevented a further 2.3 percentage point decline in the quarterly level of real GDP in 2021:q2. The magnitude of the EBP effect on GDP 
is about two to three times that implied by the monthly models of the level of the Baa-Treasury spread. One reason for the difference is that the impact of bond risk premia on the real economy is limited to particular channels in the FRBUS model, whereas it is not similarly circumscribed in the approach used by Gilchrist and Zakrajsek (2012) to estimate EBP effects on GDP. ${ }^{13}$

\section{Conclusion}

The current Covid-19 induced financial crisis and recession has created some unprecedented challenges for the Fed. The pandemic induced declines in consumption, investment and labor hours were magnified by government mandated lockdowns in the second quarter of 2020. A key component of the amplification mechanism of negative shocks in an earlier dramatic crisis and depression, 1929-33, was the financial accelerator which followed the financial collapse associated with four serious banking panics. The consequent decline in net worth and collateral by households and firms led to defaults, bankruptcies and a collapse in credit. In the Covid-19 downturn a similar dynamic has occurred as the corporate sector was hit by a collapse in sales, orders and a disrupted supply chain. This stress is evident in a spike in the Baa-10-year Treasury bond spread, a well- known measure of credit risk.

In response to the crisis, the Fed extended many of its facilities developed in the GFC of 2007-2008 to restore the plumbing of the financial system and to bolster the banking system. In the current crisis the Fed has added new facilities to shore up the corporate, municipal and small to medium business sectors. It was able to do this because of explicit Treasury guarantees against credit losses, which were not made in the GFC. A key component to the effort was the creation of the primary and secondary corporate credit facilities that were intended to support the issuance of,

\footnotetext{
${ }^{13}$ The difference may also partly owe to the EBP being a more exogenous measure of the impact of risk premia shocks, which was a big motivation for Gilchrist and Zakrajsek's (2012) study.
} 
and trading in, corporate bonds, respectively, and at non-crisis spreads over Treasury yields. The announcement of these facilities were associated with halting a rapid rise in the Baa-Treasury bond spread that was in-train in March 2020 at the height of the crisis - and seven weeks ahead of the first actual Fed purchase of corporate bond ETFs. As a result, rather than continuing to surge, this and other investment-grade corporate spreads peaked at levels seen in more normal recessions, and the spreads have subsequently ebbed.

In this paper we model the corporate Baa-Treasury spread using both monthly data from a long sample beginning in the 1920s and weekly data over a shorter sample since 1971, accounting for the major historical credit market shocks that occurred. Movements in the spread are highly correlated with the business cycles, proxied by the square of the unemployment rate.

Using this model, we show that the Fed intervention in March 2020 largely mitigated the spike in March 2020. Moreover we show, based on the estimated effects of bond spread shocks in both the FRBUS model and the model of Gilchrist and Zakrajsek (2012), that the Fed's corporate debt intervention prevented an even larger decline in real GDP, ranging from 0.6 to $2-1 / 4$ percent four quarters later. Indeed, the corporate bond facility seems to have been highly successful, so far, in mitigating the financial accelerator channel that was so damaging in the GFC and the Great Depression.

The Fed's corporate debt interventions have supplemented the Fed's other liquidity support policies and its expansionary monetary policy actions. However, this new facility —along with the new municipal bond and business loan programs - marks a major departure from earlier Fed practice which only provided support to the banking system and, since 2007, other financial institutions and markets in crises. ${ }^{14}$ Moreover, the program could induce the non-financial sector

\footnotetext{
${ }^{14}$ From its inception through the mid-1930s, the Fed conducted open market operations in bankers' acceptances. Later, in the GFC, it intervened in commercial paper. In both cases, its actions were confined to the money market, consistent
} 
to depend on Fed support in future crises or downturns. In other words, despite providing upfront benefits, together the new corporate facilities are not exactly a free lunch and their true costs and hence net benefit will depend on how they are eventually unwound and the extent of the moral hazard effects they induce.

In this regard, an important question to be considered is--had these new policies not been implemented would the Fed's other more orthodox monetary and LOLR policies have done as good a job? This may help answer the question whether the benefits of this new corporate debt support policy exceed the costs.

with the traditional central bank objective of maintaining adequate liquidity to prevent and ameliorate financial panics. The recent corporate bond market interventions go beyond that traditional lender of last resort role. 
Table 2: Nine Decade Sample Models of the Baa-Treasury Spread, 1929-2020

Long-Run Equilibrium: $\quad$ BaaTR $_{\mathrm{t}}^{*}=\alpha_{0}+\alpha_{1} U R_{\mathrm{t}}^{2}+\alpha_{2}$ PennCent $_{\mathrm{t}} \mathrm{x} U R_{\mathrm{t}}^{2}+\alpha 3$ PreAccord $_{\mathrm{t}}+\alpha_{4} C F M A_{\mathrm{t}}$

\begin{tabular}{|c|c|c|c|c|c|c|}
\hline \multirow[b]{2}{*}{ Model No. } & \multicolumn{2}{|c|}{ Annual (1931-2019) } & \multicolumn{2}{|c|}{ Monthly (1929:11-20:02) } & \multicolumn{2}{|c|}{ Monthly (1929:11-20:07) } \\
\hline & 1 & 2 & $3^{\mathrm{i}}$ & 4 & 5 & $6^{\mathrm{i}}$ \\
\hline Constant & 0.9368 & 1.0701 & 0.9601 & 1.0416 & 0.9795 & 1.0462 \\
\hline$U R_{\mathrm{t}}^{2}$ & $\begin{array}{l}0.0070^{* *} \\
(10.10)\end{array}$ & $\begin{array}{c}0.0037^{* *} \\
(4.36)\end{array}$ & $\begin{array}{c}0.0067^{* *} \\
(9.98)\end{array}$ & $\begin{array}{c}0.0054^{* *} \\
(8.57)\end{array}$ & $\begin{array}{c}0.0068^{* *} \\
(9.83)\end{array}$ & $\begin{array}{l}0.0054^{* *} \\
(8.63)\end{array}$ \\
\hline$U R_{\mathrm{t}}^{2} \mathrm{x}$ PennCent $\mathrm{t}_{\mathrm{t}}$ & $\begin{array}{c}0.0149^{* *} \\
(5.97)\end{array}$ & $\begin{array}{c}0.0178^{* *} \\
(7.00)\end{array}$ & $\begin{array}{c}0.0143^{* *} \\
(5.49)\end{array}$ & $\begin{array}{c}0.0141^{* *} \\
(5.89)\end{array}$ & $\begin{array}{l}0.0132^{* *} \\
(4.92)\end{array}$ & $\begin{array}{l}0.0142^{* *} \\
(6.02)\end{array}$ \\
\hline PreAccord $_{\mathrm{t}}$ & $\begin{array}{c}0.4373^{* *} \\
(2.69)\end{array}$ & $\begin{array}{c}0.5317^{* *} \\
(3.12)\end{array}$ & $\begin{array}{c}0.3698^{*} \\
(2.17)\end{array}$ & $\begin{array}{c}0.4228^{* *} \\
(2.70)\end{array}$ & $\begin{array}{l}0.3328 \\
(1.90)\end{array}$ & $\begin{array}{l}0.4281^{* *} \\
(2.77)\end{array}$ \\
\hline$C F M A_{\mathrm{t}}$ & $\begin{array}{c}0.8072^{* *} \\
(5.77)\end{array}$ & $\begin{array}{c}0.6281^{* *} \\
(4.39)\end{array}$ & $\begin{array}{c}0.8468^{* *} \\
(5.77)\end{array}$ & $\begin{array}{c}0.7946^{* *} \\
(5.90)\end{array}$ & $\begin{array}{l}0.9165^{* *} \\
(6.12)\end{array}$ & $\begin{array}{l}0.7822^{* *} \\
(5.89)\end{array}$ \\
\hline $\begin{array}{l}\text { unique coint. } \\
\text { vec. \# lags } \\
\text { trace no vec. } \\
\text { trace only } 1\end{array}$ & $\begin{array}{c}\text { Yes }^{* *} \\
1 \\
76.38^{* *} \\
41.04\end{array}$ & $\begin{array}{c}\text { Yes }^{* *} \\
1 \\
73.02^{* *} \\
30.37\end{array}$ & $\begin{array}{c}\text { Yes }^{* *} \\
6 \\
92.48^{* *} \\
36.12\end{array}$ & $\begin{array}{l}\text { Yes }^{* *} \\
6 \\
89.81^{* *} \\
24.62\end{array}$ & $\begin{array}{l}\text { Yes }^{* *} \\
6 \\
89.19^{* *} \\
34.94\end{array}$ & $\begin{array}{l}\text { Yes }^{* *} \\
6 \\
92.00^{* *} \\
24.71\end{array}$ \\
\hline \multicolumn{7}{|c|}{ 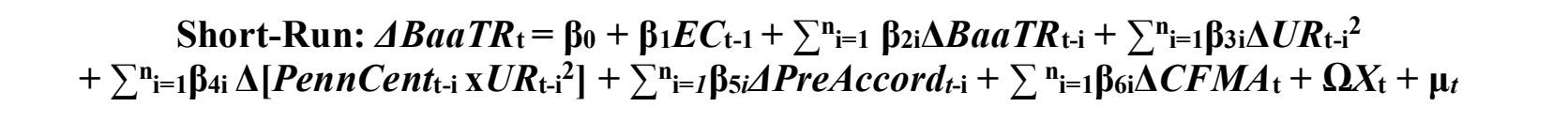 } \\
\hline$E C_{\mathrm{t}-1}$ & $\begin{array}{r}-0.216 \\
(1.24)\end{array}$ & $\begin{array}{l}-0.447^{* *} \\
(3.77)\end{array}$ & $\begin{array}{r}-0.032^{*} \\
(2.19)\end{array}$ & $\begin{array}{l}-0.052^{* *} \\
(4.46)\end{array}$ & $\begin{array}{r}-0.033^{*} \\
(2.24)\end{array}$ & $\begin{array}{r}-0.054^{* *} \\
(4.63)\end{array}$ \\
\hline annual adjust. speed: & $22 \%$ & $45 \%$ & $33 \%$ & $47 \%$ & $33 \%$ & $52 \%$ \\
\hline$\Delta B a a T R_{\mathrm{t}-1}$ & $\begin{array}{l}0.480^{* *} \\
(2.81)\end{array}$ & $\begin{array}{l}0.415^{* *} \\
(2.95)\end{array}$ & $\begin{array}{l}0.212^{* *} \\
(6.30)\end{array}$ & $\begin{array}{l}0.287^{* *} \\
(10.69)\end{array}$ & $\begin{array}{l}0.209^{* *} \\
(6.22)\end{array}$ & $\begin{array}{c}0.288^{* *} \\
(10.74)\end{array}$ \\
\hline$\Delta U R_{\mathrm{t}-\mathrm{i}}^{2}$ & $\begin{array}{r}-0.002 \\
(1.74)\end{array}$ & $\begin{array}{l}-0.003^{* *} \\
(2.70)\end{array}$ & $\begin{array}{r}0.003 \\
(3.50)\end{array}$ & $\begin{array}{l}0.001 \\
(1.26)\end{array}$ & $\begin{array}{l}0.026^{* *} \\
(3.49)\end{array}$ & $\begin{array}{l}0.001 \\
(1.29)\end{array}$ \\
\hline$\Delta\left[U R^{2} \mathrm{x} \text { PennCent }\right]_{\mathrm{t}-1}$ & $\begin{array}{c}-0.014^{*} \\
(2.43)\end{array}$ & $\begin{array}{c}-0.010^{*} \\
(2.34)\end{array}$ & $\begin{array}{l}0.006 \\
(1.86)\end{array}$ & $\begin{array}{l}0.007^{* *} \\
(2.69)\end{array}$ & $\begin{array}{l}0.006 \\
(1.70)\end{array}$ & $\begin{array}{l}0.007^{* *} \\
(2.65)\end{array}$ \\
\hline$\Delta \operatorname{PreAccord}_{\mathrm{t}-1}$ & $\begin{array}{l}0.053 \\
(0.08)\end{array}$ & $\begin{array}{l}0.088 \\
(0.18)\end{array}$ & $\begin{array}{l}0.018 \\
(0.09)\end{array}$ & $\begin{array}{r}0.029 \\
(0.19)\end{array}$ & $\begin{array}{l}0.020 \\
(0.10)\end{array}$ & $\begin{array}{l}0.029 \\
(0.19)\end{array}$ \\
\hline$\Delta C F M A_{\mathrm{t}-1}$ & $\begin{array}{l}0.309 \\
(0.52)\end{array}$ & $\begin{array}{l}0.619 \\
(1.41)\end{array}$ & $\begin{array}{r}-0.006 \\
(0.03)\end{array}$ & $\begin{array}{r}-0.006 \\
(0.04)\end{array}$ & $\begin{array}{c}-0.006 \\
(0.03)\end{array}$ & $\begin{array}{r}-0.002 \\
(0.01)\end{array}$ \\
\hline$Q E 1932_{\mathrm{t}}$ & & $\begin{array}{l}1.836^{* *} \\
(5.96)\end{array}$ & & $\begin{array}{c}2.113^{* *} \\
(18.01)\end{array}$ & & $\begin{array}{c}2.106^{* *} \\
(17.97)\end{array}$ \\
\hline USBankFail $\mathrm{t}_{\mathrm{t}}$ & & & & $\begin{array}{l}1.647^{* *} \\
(14.47)\end{array}$ & & $\begin{array}{l}1.646^{* *} \\
(14.47)\end{array}$ \\
\hline
\end{tabular}




\begin{tabular}{|c|c|c|c|c|c|c|}
\hline BkCrisis $33_{\mathrm{t}-1}$ & & & & $\begin{array}{l}0.708^{* *} \\
(5.54)\end{array}$ & & $\begin{array}{l}0.710^{* *} \\
(5.56)\end{array}$ \\
\hline DGold $34 \mathrm{t}$ & & $\begin{array}{r}-0.533 \\
(1.24)\end{array}$ & & $\begin{array}{c}-0.560^{* *} \\
(3.40)\end{array}$ & & $\begin{array}{c}-0.557^{* *} \\
(3.39)\end{array}$ \\
\hline DLehman $_{\mathrm{t}}$ & & $\begin{array}{l}1.790^{* *} \\
(4.49)\end{array}$ & & $\begin{array}{l}1.429^{* *} \\
(9.01)\end{array}$ & & $\begin{array}{l}1.443^{* *} \\
(9.10)\end{array}$ \\
\hline Covid $_{\mathrm{t}}$ & & & & & & $\begin{array}{l}1.287^{* *} \\
(8.18)\end{array}$ \\
\hline Covid $_{\mathrm{t}-1}$ & & & & & & $\begin{array}{r}-0.252 \\
(1.57)\end{array}$ \\
\hline Covid $_{\mathrm{t}-2}$ & & & & & & $\begin{array}{l}0.137 \\
(0.83)\end{array}$ \\
\hline Constant & $\begin{array}{r}-0.001 \\
(0.01) \\
\end{array}$ & $\begin{array}{r}-0.060 \\
(1.37) \\
\end{array}$ & $\begin{array}{r}-0.001 \\
(0.29) \\
\end{array}$ & $\begin{array}{r}-0.001 \\
(0.28) \\
\end{array}$ & $\begin{array}{l}0.000 \\
(0.05) \\
\end{array}$ & $\begin{array}{r}-0.002 \\
(0.41) \\
\end{array}$ \\
\hline$\overline{\mathrm{Adj} .} \mathrm{R}^{2}$ & 0.059 & 0.477 & 0.100 & 0.443 & 0.100 & 0.462 \\
\hline S.E. & 0.528 & 0.393 & 0.200 & 0.157 & 0.203 & 0.157 \\
\hline VEC Auto (1) & 24.64 & 27.40 & 23.92 & 22.01 & 23.61 & 21.52 \\
\hline VEC Auto (2) & 23.66 & 13.60 & 23.58 & 27.81 & 22.98 & 27.22 \\
\hline VEC Auto (4) & 9.81 & 12.86 & $44.38^{* *}$ & 23.66 & $45.31^{* *}$ & 23.81 \\
\hline
\end{tabular}

Notes: Absolute t-statistics are in parentheses and ${ }^{* *}\left(^{*}\right)$ denoted significant at the $99 \%$ (95\%) confidence level. (i) Coefficients for the $U R^{2}$ terms are multiplied by $(1-$ Corp $)$ in models 3 and 6. (ii) Absolute tstatistics in parentheses. (iii) Long-run: Maximum likelihood estimates of the long-run equilibrium relationship using a two-equation system with at most one cointegrating vector. (iv) $E C_{\mathrm{t}-1}=B a a T R_{\mathrm{t}-1}-$ $\alpha_{0}+\alpha_{1} U R_{\mathrm{t}-1}^{2}+\alpha_{2}$ PennCent $_{\mathrm{t}-1} \times$ UR $_{\mathrm{t}-1}^{2}+\alpha 3$ PreAccord $_{\mathrm{t}-1}+\alpha_{4}$ CFMA $_{\mathrm{t}-1}$. (v) First difference terms of elements in the long-run cointegrating vector. (vi) Lag lengths chosen to minimize the AIC criterion. (vii) significance of the trace and VEC Auto statistics reflects lag length and if a time trend is included in the long-run. 
Table 3: Half-Century Sample Models of the Baa-Treasury Spread, 1971-2020

Long-Run Equilibrium: BaaTR $_{\mathrm{t}}^{*}=\alpha_{0}+\alpha_{1} U R_{\mathrm{t}}{ }^{2}+\alpha_{2} C F M A_{\mathrm{t}}$

\begin{tabular}{|c|c|c|c|c|c|c|}
\hline \multirow[b]{3}{*}{ Model No. } & \multicolumn{3}{|c|}{ Weekly } & \multicolumn{3}{|c|}{ Monthly } \\
\hline & \multicolumn{2}{|c|}{$5 / 7 / 71-02 / 28 / 20$} & \multirow{2}{*}{$\frac{5 / 71-7 / 20}{3^{i}}$} & \multicolumn{2}{|c|}{ May 1971-Feb. 2020} & \multirow{2}{*}{$\frac{5 / 71-7 / 20}{6^{i}}$} \\
\hline & 1 & 2 & & 4 & 5 & \\
\hline Constant & 1.3682 & 1.3646 & 1.3774 & 1.3921 & 1.4689 & 1.5021 \\
\hline$U R_{\mathrm{t}}^{2}$ & $\begin{array}{c}0.0136^{* *} \\
(4.29)\end{array}$ & $\begin{array}{c}0.0137^{* *} \\
(4.42)\end{array}$ & $\begin{array}{c}0.0135^{* *} \\
(4.36)\end{array}$ & $\begin{array}{c}0.0133^{* *} \\
(3.48)\end{array}$ & $\begin{array}{c}0.0121^{\text {** }} \\
(3.59)\end{array}$ & $\begin{array}{c}0.0116^{* *} \\
(3.21)\end{array}$ \\
\hline$C F M A_{\mathrm{t}}$ & $\begin{array}{c}0.7394^{* *} \\
(5.23)\end{array}$ & $\begin{array}{c}0.7381^{* *} \\
(5.34)\end{array}$ & $\begin{array}{c}0.7457^{* *} \\
(5.38)\end{array}$ & $\begin{array}{c}0.7252^{* *} \\
(4.48)\end{array}$ & $\begin{array}{c}0.6540^{* *} \\
(4.57)\end{array}$ & $\begin{array}{c}0.6351^{* *} \\
(4.17)\end{array}$ \\
\hline unique coint. & $\mathrm{Yes}^{* *}$ & Yes $^{* *}$ & Yes $^{* *}$ & Yes $^{* *}$ & $\mathrm{Yes}^{* *}$ & $\mathrm{Yes}^{* *}$ \\
\hline vec. \# lags & 12 & 12 & 12 & 6 & 6 & 6 \\
\hline trace no vec. & $56.16^{* *}$ & $59.07^{* *}$ & $59.46^{* *}$ & $41.27^{* *}$ & $41.27^{* *}$ & $43.89^{* *}$ \\
\hline trace only 1 & 9.15 & 9.71 & 10.01 & 12.79 & 12.79 & 12.11 \\
\hline
\end{tabular}

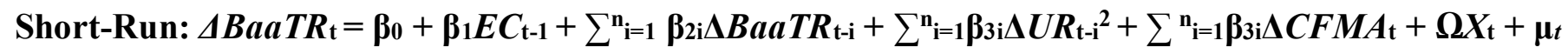

\begin{tabular}{|c|c|c|c|c|c|c|}
\hline$E C_{\mathrm{t}-1}$ & $\begin{array}{c}-0.017^{* *} \\
(4.40)\end{array}$ & $\begin{array}{c}-0.017^{* *} \\
(4.57)\end{array}$ & $\begin{array}{c}-0.017^{* *} \\
(4.54)\end{array}$ & $\begin{array}{c}-0.075^{* *} \\
(4.28)\end{array}$ & $\begin{array}{c}-0.086^{*} \\
(5.23)\end{array}$ & $\begin{array}{c}-0.083^{* *} \\
(4.94)\end{array}$ \\
\hline annual adjust. speed: & $58 \%$ & $56 \%$ & $58 \%$ & $61 \%$ & $66 \%$ & $64 \%$ \\
\hline$\Delta B a a T R_{\mathrm{t}-1}$ & $\begin{array}{c}0.225^{* *} \\
(11.26)\end{array}$ & $\begin{array}{c}0.231^{* *} \\
(11.88)\end{array}$ & $\begin{array}{c}0.233^{* *} \\
(11.91)\end{array}$ & $\begin{array}{l}0.419^{* *} \\
(9.95)\end{array}$ & $\begin{array}{l}0.391^{* *} \\
(9.85)\end{array}$ & $\begin{array}{l}0.377^{* *} \\
(9.28)\end{array}$ \\
\hline$\Delta U R_{\mathrm{t}-1}^{2}$ & $\begin{array}{l}0.001 \\
(0.58)\end{array}$ & $\begin{array}{l}0.001 \\
(1.06)\end{array}$ & $\begin{array}{l}0.001 \\
(1.05)\end{array}$ & $\begin{array}{l}0.005 \\
(1.44)\end{array}$ & $\begin{array}{c}0.006^{*} \\
(1.95)\end{array}$ & $\begin{array}{l}0.007^{*} \\
(2.11)\end{array}$ \\
\hline$\triangle C F M A_{\mathrm{t}-1}$ & $\begin{array}{l}0.020 \\
(0.22)\end{array}$ & $\begin{array}{l}0.019 \\
(0.21)\end{array}$ & $\begin{array}{l}0.018 \\
(0.21)\end{array}$ & $\begin{array}{r}-0.014 \\
(0.09)\end{array}$ & $\begin{array}{r}-0.008 \\
(0.05)\end{array}$ & $\begin{array}{r}-0.007 \\
(0.04)\end{array}$ \\
\hline StockCrash $87 \mathrm{t}$ & & $\begin{array}{l}0.757^{* *} \\
(8.61)\end{array}$ & $\begin{array}{l}0.759^{* *} \\
(8.63)\end{array}$ & & & \\
\hline Sept11 $1_{\mathrm{t}}$ & & $\begin{array}{l}0.257^{* *} \\
(2.94)\end{array}$ & $\begin{array}{l}0.257^{* *} \\
(2.94)\end{array}$ & & & \\
\hline USDGrade $_{\mathrm{t}}$ & & $\begin{array}{l}0.284^{* *} \\
(3.24)\end{array}$ & $\begin{array}{l}0.284^{* *} \\
(3.24)\end{array}$ & & & \\
\hline DLehman $_{\mathrm{t}}$ & & $\begin{array}{l}0.360^{* *} \\
(4.11)\end{array}$ & $\begin{array}{l}0.360^{* *} \\
(4.11)\end{array}$ & & $\begin{array}{l}1.430^{* *} \\
(8.50)\end{array}$ & $\begin{array}{l}1.443^{* *} \\
(8.56)\end{array}$ \\
\hline
\end{tabular}

Covid $\mathrm{t}-1$,

$-0.049$

(1.72) 


\begin{tabular}{|c|c|c|c|c|c|c|}
\hline$\Delta$ Covid $_{\mathrm{t}}$ & & & $\begin{array}{l}0.672^{* *} \\
(7.24)\end{array}$ & & & $\begin{array}{l}1.264 \\
(7.61)\end{array}$ \\
\hline$\Delta$ Covid $_{\mathrm{t}-1}$ & & & $\begin{array}{l}0.244^{*} \\
(2.60)\end{array}$ & & & $\begin{array}{r}-0.324 \\
(1.87)\end{array}$ \\
\hline$\Delta$ Covid $_{\mathrm{t}-2}$ & & & $\begin{array}{c}-0.219^{*} \\
(2.30)\end{array}$ & & & $\begin{array}{l}0.209 \\
(1.16)\end{array}$ \\
\hline Constant & $\begin{array}{r}-0.000 \\
(0.02) \\
\end{array}$ & $\begin{array}{r}-0.001 \\
(0.39) \\
\end{array}$ & $\begin{array}{r}-0.001 \\
(0.43) \\
\end{array}$ & $\begin{array}{r}-0.001 \\
(0.09) \\
\end{array}$ & $\begin{array}{r}-0.003 \\
(0.47) \\
\end{array}$ & $\begin{array}{r}-0.005 \\
(0.67)\end{array}$ \\
\hline$\overline{\mathrm{Adj} .} \mathrm{R}^{2}$ & 0.074 & 0.111 & 0.157 & 0.172 & 0.266 & 0.318 \\
\hline S.E. & 0.089 & 0.087 & 0.087 & 0.176 & 0.165 & 0.166 \\
\hline VEC Auto (1) & 5.53 & 2.90 & 3.40 & 7.43 & 12.05 & 9.70 \\
\hline VEC Auto (2) & 2.33 & 7.13 & 6.18 & 8.79 & 3.33 & 9.19 \\
\hline VEC Auto (4) & 9.06 & 13.12 & 9.75 & 3.11 & 6.43 & 14.04 \\
\hline
\end{tabular}

Notes: Absolute t-statistics are in parentheses and ${ }^{* *}\left(^{*}\right)$ denoted significant at the $99 \%$ (95\%) confidence level. (i) Coefficients for the $U R^{2}$ terms are multiplied by $(1-\operatorname{Corp})$ in models 3 and 6. (ii) Absolute tstatistics in parentheses. (iii) Long-run: Maximum likelihood estimates of the long-run equilibrium relationship using a two-equation system with at most one cointegrating vector. (iv) $E C_{\mathrm{t}-1}=B a a T R_{\mathrm{t}-1}-$ $\alpha_{0}+\alpha_{1} U R_{\mathrm{t}-1}^{2}+\alpha_{2} C F M A_{\mathrm{t}-1}$. (v) First difference terms of elements in the long-run cointegrating vector. (vi) Lag lengths chosen to minimize the AIC criterion. (vi) significance of the trace and VEC Auto statistics reflects lag length and if a time trend is included in the long-run. 
Table 5: Modeling the Excess Bond Premium, 1973-2020

$$
E B P_{\mathrm{t}}=\alpha_{0}+\alpha_{2} \Delta U R_{\mathrm{t}-2}+\sum \alpha_{\mathrm{i}} E B P_{\mathrm{t}-\mathrm{i}}+\alpha_{7} \text { DCovid }_{\mathrm{t}}
$$

Sample:

$\begin{array}{cccc}\text { PreCovid } & \text { Full } & \text { Full } & \text { Full } \\ \text { 1973:06- } & 1973: 06- & 1973: 06- & 1973: 06- \\ \text { 2020:02 } & 2020: 07 & 2020: 07 & 2020: 07\end{array}$

$\underline{\text { Model } 1} \quad \underline{\text { Model } 2} \quad \underline{\text { Model } 3} \quad \underline{\text { Model } 4}$

Constant

$\begin{array}{llll}0.007 & 0.006 & 0.004 & 0.050 \\ (0.68) & (0.55) & (0.38) & (0.49)\end{array}$

$\triangle U R_{\mathrm{t}-2}$

$\begin{array}{llll}0.132^{*} & 0.024 & -0.026 & 0.133^{*}\end{array}$

$x$ FedxBond in Model 4

(1.08)

(1.20)

$E B P_{\mathrm{t}-1,}$

$\begin{array}{cccc}0.702^{* *} & 0.705^{* *} & 0.704^{* *} & 0.705^{* *} \\ (16.81) & (16.86) & (17.29) & (17.39)\end{array}$

$E B P_{\mathrm{t}-2,}$

$0.236^{* *}$

$0.226^{* *}$

$0.229^{* *}$

$0.224^{* *}$

(4.40)

(4.59)

(4.49)

$E B P_{\mathrm{t}-3,}$

$$
0.055
$$

0.055

0.058

0.041

(1.05)

(1.03)

(1.12)

(0.81)

$E B P_{\mathrm{t}-4}$

$$
0.052
$$

0.065

0.061

0.063

(1.02)

(1.26)

(1.22)

(1.27)

$E B P_{\mathrm{t}-5}$,

$-0.162^{* *}$

$-0.152^{* *}$

$-0.150^{* *}$

$-0.150^{* *}$

(3.87)

(3.61)

(3.65)

(3.67)

DCovid $_{\mathrm{t}}$

$$
1.358^{* *} \quad 1.337^{* *}
$$

(5.67)

Adj. $R^{2}$

0.819

0.817

(5.60)

S.E.

0.238

0.806

0.239

0.818

LM (1)

0.72

0.246

0.01

0.238

LM (2)

3.35

0.93

0.03

0.00

LM (4)

3.57

2.84

1.28

0.00

Q (24)

31.75

28.41

31.02

2.09

Notes: ${ }^{* *}\left({ }^{*}\right)$ significant at the $99 \%(95 \%)$ confidence level. 


\section{References}

Agarwal, Sumit, Jacqueline Barrett, Crystal Cun, and Mariacristina De Nardi. 2010. "The AssetBacked Securities Markets, the Crisis, and TALF." Economic Perspectives 34 (4): 10115.

Bagehot, Walter. 1873. Lombard Street: A Description of the Money Market. London: Henry S. King \& Company.

Bernanke, Ben S. 1983. Non-Monetary Effects of Financial Crises in the Propagation of the Great Depression.” American Economic Review 71, 257-276.

Bernanke, Ben. 1995. "The Macroeconomics of the Great Depression: A Comparative Approach." Journal of Money, Credit, and Banking 27 (1): 1-28. https://doi.org/10.2307/2077848

Bernanke, Ben S. 2018. "The Real Effects of Disrupted Credit: Evidence from the Global Financial Crisis." Brookings Papers on Economic Activity 49 (2): 251-342. https://doi.org/10.1353/eca.2018.0012

Bernanke, Ben, and Mark Gertler. 1990. "Financial Fragility and Economic Performance." Quarterly Journal of Economics 105 (1), 87-114. https://doi.org/10.2307/2937820

Bernanke, Ben S., Mark Gertler, and Simon Gilchrist. 1996. "The Financial Accelerator and the Flight to Quality." Review of Economics and Statistics 78 (1): 1-15. https://doi.org/10.2307/2109844

Bernanke, Ben, Mark Gertler, and Simon Gilchrist. 1999. "The Financial Accelerator in a Quantitative Business Cycle Framework.” In Handbook of Macroeconomics, Vol. 1C, edited by J. B. Taylor and M. Woodford, 1341-93. Amsterdam: Elsevier Science, NorthHolland. https://doi.org/10.1016/S1574-0048(99)10034-X 
Bolton, Patrick and Martin Oehmke. 2015. "Should Derivatives Be Privileged in Bankruptcy?" Journal of Finance 70 (6): 2353-94. https://doi.org/10.1111/jofi.12201

Bordo, Michael D. 2008. "An Historical Perspective on the Crisis of 2007-2008." NBER Working Paper 14569. https://doi.org/10.3386/w14569

Bordo, Michael D. 2014. "Rules for a Lender of Last Resort: An Historical Perspective. " Journal of Economic Dynamics and Control 49 (C): 126-134. https://doi.org/10.1016/j.jedc.2014.09.023

Bordo, Michael D., John V. Duca, and Christoffer Koch. 2016. "Economic Policy Uncertainty and the Credit Channel: Aggregate and Bank Level U.S. Evidence over Several Decades.” Journal of Financial Stability 26, 90-106. https://doi.org/10.1016/j.jfs.2016.07.002

Bordo, Michael D., and Christopher M. Meissner. 2016. "Fiscal and Financial Crises.” NBER Working Paper 22059. https://doi.org/10.3386/w22059

Bordo, Michael D., and Sinha, Arunima. Forthcoming. “The 1932 Federal Reserve Open Market Purchases as a Precedent for Quantitative Easing." Journal of Money, Credit, and Banking.

Bordo, Michael D., and David C. Wheelock. 2011. "The Promise and Performance of the Federal Reserve as Lender of Last Resort 1914-1933.” NBER Working Paper 16763. https://doi.org/10.3386/w16763

Bureau of Labor Statistics. 2020. "The Impact of the Coronavirus (COVID-19) Pandemic on The Employment Situation for June 2020.”July 2, 2020. https://www.bls.gov/cps/employmentsituation-covid19-faq-june-2020.pdf 
Calomiris, Charles W. Douglas Holtz-Eakin, R. Glenn Hubbard 2 Allan H. Meltzer, and Hal S. Scott. 2017. "Establishing Credible Rules for Fed Emergency Lending.” Journal of Financial Economic Policy 9 (3): 260-67. https://doi.org/10.1108/JFEP-01-2017-0006

Cleary, Aisling, Joyce Kwok, and Rob Valletta. 2009. "New Highs in Unemployment Insurance Claims." FRBSF Economic Letter, Federal Reserve Bank of San Francisco, September. DiMartino, Danielle, John V. Duca, and Jessica Renier. 2009. "Fed Confronts Financial Crisis By Expanding Its Role As Lender of Last Resort,” Economic Letter, Federal Reserve Bank of Dallas, February/March 2009. <http://www.dallasfed.org/assets/documents/research/eclett/2009/el0902.pdfs

Duca, John V. 1999. "What Credit Market Indicators Tell Us,” Federal Reserve Bank of Dallas Economic and Financial Policy Review 1999:q3: 2-13. https://www.dallasfed.org/ /media/documents/research/efr/1999/efr9903a.pdf

Duca, John V. 2013a. "Did the Commercial Paper Funding Facility Prevent a Great Depression Style Money Market Meltdown?” Journal of Financial Stability 9: 747-758. https://doi.org/10.1016/j.jfs.2012.04.002

Duca, John V. 2013b. “The Money Market Meltdown of the Great Depression,” Journal of Money, Credit, and Banking 45: 493-504. https://doi.org/10.1111/jmcb.12012

Duca, John V. 2013c. “The Subprime Mortgage Crisis,” Federal Reserve System History Gateway Essay, November 2013, $\underline{\text { http://stage.federalreservehistory.org/Events/DetailView/55 }}$

Duca, John V. 2017. "The Great Depression Versus the Great Recession in the U.S.: How Fiscal, Monetary, and Financial Policies Compare.” Journal of Economic Dynamics and Control 81: 32-49. https://doi.org/10.1016/j.jedc.2017.05.008 
Duca, John V., and David C. Ling. 2020. "The Other (Commercial) Real Estate Boom and Bust: the Effects of Risk Premia and Regulatory Capital Arbitrage." Journal of Banking and Finance 112(C): https://doi.org/10.1016/j.jbankfin.2018.03.006

Duca, John V., John Muellbauer, and Anthony Murphy. 2010. "Housing Markets and the Financial Crisis of 2007-2009: Lessons for the Future," Journal of Financial Stability 6: 203-17. https://doi.org/10.1016/j.jfs.2010.05.002

Duca, John V. and Anthony Murphy. 2013. "Would a Bagehot Style Corporate Bond Backstop Have Helped Counter the Great Recession?” Economics Letters 119(3): 351-53. https://doi.org/10.1016/j.econlet.2013.02.010

Edwards, Sebastian. 2018. American Default: The Untold Story of FDR, the Supreme Court, and the Battle over Gold. Princeton University Press, Princeton. https://doi.org/10.23943/9781400890385

Favara, Giovanni, Simon Gilchrist, Kurt F. Lewis, and Egon Zakrajsek (2016). "Recession Risk and the Excess Bond Premium," FEDS Notes. Washington: Board of Governors of the Federal Reserve System, April 8, 2016, http://dx.doi.org/10.17016/2380-7172.1739.

Fisher, Irving. 1933. "The Debt Deflation Theory of Great Depressions.” Econometrica 1 (4): 337 - 357 https://doi.org/10.2307/1907327

Freixas, Xavier, Curzio Giannini, Glenn Hoggarth, and Farouk Soussa. 1999. "Lender of Last Resort: a Review of the Literature." Financial Stability Review 7, Bank of England. 15167.

Freixas, Xavier, Bruno M. Parigi and Jean-Charles Rochet. 2004. "The Lender of Last Resort: A Twenty-First Century Approach.” Journal of the European Economic Association 2 (6): 1085-1115. https://doi.org/10.1162/1542476042813841

Friedman, M., Schwartz, A.J., 1963. A Monetary History of the United States 1867-1960. 
Princeton University Press, Princeton.

Gilchrist, Simon and Egon Zakrajsek. 2012. "Credit Spreads and Business Cycle Fluctuations." American Economic Review 102 (4): 1692-1720. https://doi.org/10.1257/aer.102.4.1692

Gorton, Gary and Andrew Metrick. 1999. “The Federal Reserve and Panic Prevention: The Roles of Financial Regulation and Lender of Last Resort." Journal of Economic Perspectives $13(4): 45-64$.

Gorton, Gary, and Andrew Metrick. 2013. "The Federal Reserve and Panic Prevention: The Roles of Financial Regulation and Lender of Last Resort." Journal of Economic Perspectives 27 (4): 45-64. https://doi.org/10.1257/jep.27.4.45

Humphries, Thomas M. 1989. "Lender of Last Resort: The Concept in History.” Federal Reserve Bank of Richmond Economic Review March/April: 8-16.

Jaffee, Dwight M. 1975. "Cyclical Variations in the Risk Structure of Interest Rates." Journal of Monetary Economics 1 (3): 309-25. https://doi.org/10.1016/0304-3932(75)90016-1

Johansen, Soren. 1995. Likelihood-Based Inference in Cointegrated Vector Autoregressive Models. New York: Oxford University Press. https://doi.org/10.1093/0198774508.001.0001

Judge, Kathryn. 2016. “The First Year: The Role of a Modern Lender of Last Resort.” Columbia Law Review 116 (3): 843-926.

Kaufman, George G. 1991. "Lender of Last Resort: A Contemporary Perspective.” Journal of Financial Services Research 5 (2): 95-110. https://doi.org/10.1007/BF00114030

LaForte, Jean-Philippe. 2018. "Overview of the Changes to the FRB/US Model." Figure 3. Feds Notes. December 7. https://www.federalreserve.gov/econres/notes/feds-notes/overviewof-the-changes-to-the-frb-us-model-2018-20181207.htm 
https://www.federalreserve.gov/econres/notes/feds-notes/overview-of-the-changes-to-thefrb-us-model-2018-accessible-20181207.htm\#fig3

Levy, Mickey D. 2020. “The Fed's Aggressive Response to the Crisis: What's Next?”

Economics Macro News, Berenberg Capital Markets,

Mishkin, Frederic S. 1991. “Asymmetric Information and Financial Crises: A Historical

Perspective." In Financial Markets and Financial Crises, pp. 69-108. R. Glenn Hubbard (ed.). Chicago: University of Chicago Press.

Mishkin, Frederic S. and Eugene N. White. 2002. "U.S. Stock Market Crashes and Their Aftermath: Implications for Monetary Policy.” NBER Working Paper 8992. https://doi.org/10.3386/w8992

Moody’s Investor Service. 2011. “Corporate Default and Recovery Rates, 1920-2010.” Special Report. Global Corporate Finance.

Powell, Jerome H. 2020. “Current Economic Issues.” Speech at the Peterson Institute for International Economics, Washington, D.C., May 13, 2020. https://www.federalreserve.gov/newsevents/speech/powell20200513a.htm

Stout, Lynn A. 2011. "Derivatives and the Legal Origin of the 2008 Credit Crisis." Harvard Business Law Review 1 (1): 1-38.

Tallman, Ellis and Eugene White. 2020. "Why Was There No Banking Panic in 1920-1921? The Federal Reserve Banks and the Recession." Unpublished manuscript, Federal Reserve Bank of Cleveland and Rutgers University.

Tucker, Paul. 2014. “The Lender of Last Resort and Modern Central Banking: Principles and Reconstruction.” In Re-thinking the Lender of Last Resort. BIS Papers No 79. Basel: Bank for International Settlements. 


\section{Appendix A: Consistently Tracking Unemployment Since the Late 1920s}

Our primary source of data on the unemployment rate is the headline, U-3 series from by the BLS, available on a monthly basis since January 1948 and on an annual basis since 1929. Definitional differences make inconsistent pre- and post-1943 readings, with differences in monthly sources before 1948 adding additional complications for tracking monthly unemployment. This appendix discusses how we constructed consistent measures of the unemployment from available data sources. In creating monthly estimates, we tried to adjust pre1948 data from non-BLS sources to be in line with monthly BLS data that start in January 1948.

\section{A1. Splicing Several Series}

From 1929 to 1939 two series overlap. These are the annual unemployment rate from the BLS and a monthly series (April 1929-December 1939) from the Conference Board. The annual averages of the latter series are notably below those of the BLS data. We interpolate the annual differences into monthly adjustments, which we add to the Conference Board monthly series to yield a monthly series from April 1929 to December 1939. From January 1940 to December 1947 our source of monthly data is the Census's Monthly Earnings and Employment Report, which overlap with the post-1948 BLS series. For the first three months of 1948, the Census series average 0.7 percentage point below that of the BLS series. We added this difference to the January 1940-December 1947 readings of the Census series. Connecting these three segments yields our basic monthly series, which spans April 1929 through the present.

\section{A2. Adjusting 1933-43 Data for Omitting Public Works’ Employees (Darby, 1976)}

As stressed by Darby (1976), annual statistics from the BLS on the unemployment rate are understated by the exclusion of employees in New Deal public works projects from calculations of the number of employed and the workforce. Using data on such excluded workers, Darby (1976) provides annual statistics corrected for this omission, and notes that the effects were quite large in 
the mid-and late 1930s. We can directly adjust our annual spliced series by subtracting Darby's implied annual net effects for 1933-43, which avoids the prior splicing of endpoints.

Our monthly spliced series was adjusted in several steps. First, we used Darby's annual estimated effect as the effect for the second quarter of a calendar year reflecting that the timing of effects may be slightly skewed to the first half of a calendar year owing to budgets operating on a fiscal year basis ( $\mathrm{q} 4$ of year $\mathrm{t}-1$ through $\mathrm{q} 3$ of year $\mathrm{t}$ ). Then we used a cubic spline to interpolate from annual to monthly effects, which were then used to adjust the spliced monthly series. As shown in Figure A-1 the difference between the Darby-adjusted and unadjusted series is notable in the Great Depression years. Consistent with Darby's (1976) point about the inconsistencies between unemployment statistics across the Great Depression and the post-WWII period, we find stronger evidence of cointegration and a stronger linkage between the corporate Baa-Treasury

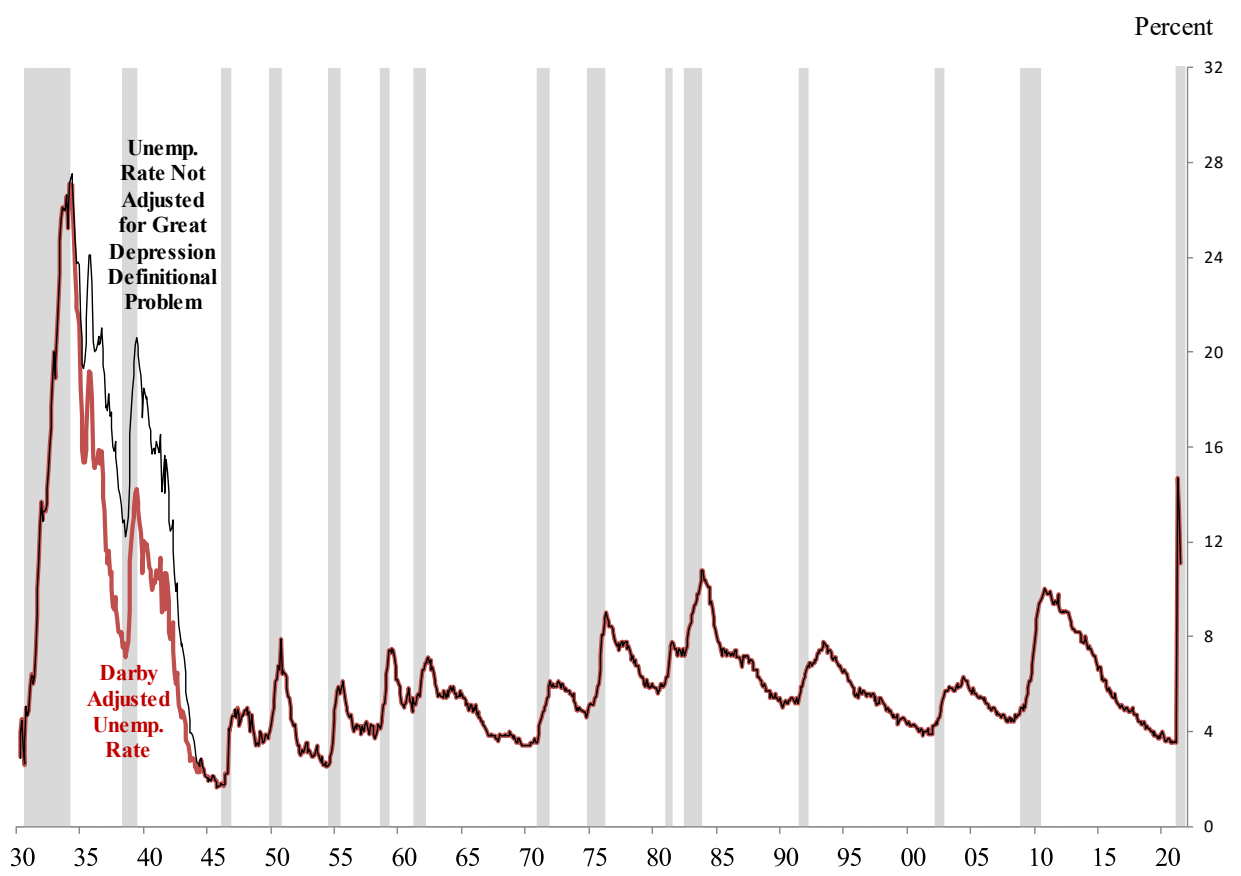

Figure A-1: Adjusting the Headline Unemployment Rate for Omissions of Special Public Works' Employees During the Great Depression (Sources: BLS, NBER Macro-History database, and authors' calculations.) 
yield spread and unemployment using the Darby-adjusted series than using the unadjusted series.

\section{A.3. Adjustments to the Unemployment Rate for Misclassified Unemployed Workers}

There is general concern among economists that, since March 2020, the headline (U-3) unemployment rate has been under-stated by the misclassification of unemployed workers who were being paid to remain on company payrolls. Under the 2020 CARES Act, many small firms qualified for forgivable loans aimed at covering business expenses during the Covid-19 Recession if firms continued to pay and keep workers on their payrolls for 8 weeks. This incentive to retain workers not on the job likely induced a large rise in the number of employed persons who had a job but were not at work. For example, the number with a job but not at work ranged between 3.91 and 4.25 million in the month of May for the years 2016-2019, but was much higher $(8.35$ million) in May 2020.

The household survey also solicits explicit reasons for not being at work whilst employed include vacation, illness, child-care problems, other family/personal obligations, labor disputes, poor weather, maternity/paternity leave, school/training, and civic/military duty. There is an "other category" entry, which saw outsized readings from March to July 2020 compared to the

same months in recent, prior years. This surge plausibly includes people who were absent due to temporary, pandemic-related closures that were misclassified as employed but not working instead of being classified as unemployed. The number of people who were not at work for "other reasons" was around 0.9 million for most months in recent years, but jumped to as much as 8.1 million in April 2020, before falling to 5.4 and then 2.8 million in May and June 2020, respectively.

The BLS provides an upper bound gauge of the misclassification effect assuming that all of the number of employed people who were not at work for "other reasons" that exceeded its average in recent years owed solely to misclassification, and assuming that all such people expected to be recalled and were able to work. This series (URCov) likely provides a more accurate 
gauge of unemployment, per se. However, insofar as the gap between the U-3 and URCov series (see Figure A-2) mainly owes to government subsidies to business to maintain employment links, the U-3 series may provide a more relevant gauge of how slack relates to cyclical default risk on bonds. Consistent with this view, the long-spliced series using the post-1948 U-3 rate outperformed that using the URCov series instead and for this reason, the analysis uses the URSp series in monthly and annual regressions.

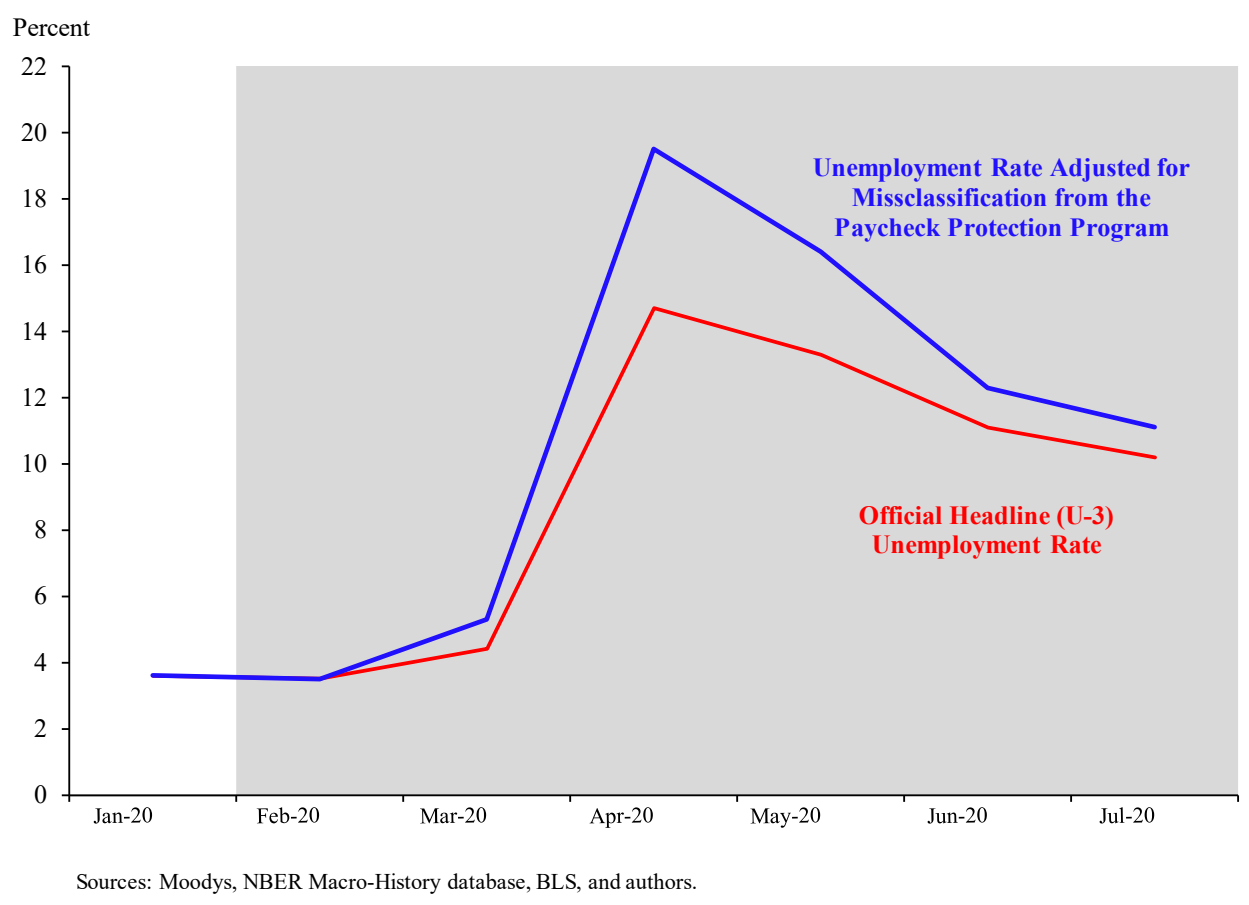

Figure A-2: Adjusting the Headline Unemployment Rate for Survey Misclassifications (Source: BLS) 


\section{Appendix B: KPSS Stationarity Tests}

(with time trend)

Annual (1929-2019)

\begin{tabular}{|c|c|c|c|c|c|}
\hline \multirow[b]{2}{*}{ BaaTR } & \multicolumn{3}{|c|}{ Stationarity (bandwidth) } & \multicolumn{2}{|c|}{ Stationarity (bandwidth) } \\
\hline & $0.2095^{*}$ & $(6)$ & $\triangle B a a T R$ & 0.0945 & $(18)$ \\
\hline$U R$ & $0.1297^{+}$ & (6) & $\Delta U R$ & 0.0421 & (1) \\
\hline \multicolumn{6}{|c|}{ Monthly (April 1929 - July 2020) } \\
\hline & \multicolumn{3}{|c|}{ Stationarity (bandwidth) } & \multicolumn{2}{|c|}{ Stationarity (bandwidth } \\
\hline BaaTR & $0.4585^{* *}$ & $(25)$ & $\triangle$ BaaTR & 0.0157 & $(15)$ \\
\hline \multirow[t]{3}{*}{$U R$} & $0.2892^{+}$ & $(25)$ & $\Delta U R$ & 0.0437 & $(15)$ \\
\hline & \multicolumn{5}{|c|}{ Weekly (January 1971 - August 7 2020) } \\
\hline & \multicolumn{3}{|c|}{ Stationarity (bandwidth) } & \multicolumn{2}{|c|}{ Stationarity (bandwidth) } \\
\hline BaaTR & $0.1349^{+}$ & $(40)$ & $\triangle$ BaaTR & 0.0145 & (4) \\
\hline \multirow[t]{3}{*}{$U R$} & $0.2157^{*}$ & $(0)$ & $\triangle U R$ & 0.0363 & (19) \\
\hline & \multicolumn{5}{|c|}{ Monthly (January 1973 - July 2020) } \\
\hline & \multicolumn{3}{|c|}{ Stationarity (bandwidth) } & \multicolumn{2}{|c|}{ Stationarity (bandwidth) } \\
\hline$E B P$ & 0.0387 & $(17)$ & $\triangle E B P$ & 0.0118 & (4) \\
\hline$U R$ & $0.1353^{+}$ & $(40)$ & $\Delta U R$ & 0.0595 & (6) \\
\hline
\end{tabular}

Notes: ${ }^{*}$ and ${ }^{* *}$ denote $95 \%$ and $99 \%$ significance levels, respectively. Lag lengths for the KPSS stationarity tests are based on the Newey-West bandwidth selector using a Bartlett kernel for the spectral estimation method. The combination of a significant KPSS stationary test statistic on the level of a variable (rejecting that it is stationary) and a significant test statistic on its first difference (accepting it is stationary) is evidence against trend stationarity. 


\section{Appendix C: Post-Covid Long-Run Relationships}

\section{Long Sample, Pre Covid Monthly Model:}

$$
\begin{aligned}
& \text { BaaTR }_{\mathrm{t}}=1.042+0.005 \times U R_{\mathrm{t}}^{2 * *}+0.014\left[\text { PennCentral } \mathrm{t}_{\mathrm{t}} U R_{\mathrm{t}}{ }^{2}\right]^{* *} \quad \text { (Monthly Model) } \\
& \text { (0.001) (0.002) } \\
& +0.423 \text { PreAccord }_{\mathrm{t}}^{* *}+0.795 \text { CFMA }_{\mathrm{t}}^{* *} \quad \text { Speed of adjustment: } 0.47 / \text { year } \\
& \text { (0.156) }
\end{aligned}
$$

\section{Long Sample, Covid-Adjusted Monthly Model:}

$$
\begin{aligned}
& \text { BaaTR }_{\mathrm{t}}=1.046+0.005 \times U R_{\mathrm{t}}^{2^{* *}}+0.014\left[\text { PennCentral } \mathrm{x}_{\mathrm{x}} U R_{\mathrm{t}}{ }^{2}\right]^{* *} \quad \text { (Monthly Model) } \\
& \text { (0.001) (0.002) } \\
& +0.428 \text { PreAccord }_{\mathrm{t}}^{* *}+0.782 \text { CFMA }_{\mathrm{t}}^{* *} \quad \text { Speed of adjustment: } 0.52 / \text { year } \\
& \text { (0.155) (0.133) }
\end{aligned}
$$

Notes: Absolute standard errors are on parentheses. ${ }^{* *}\left(^{*}\right)$ significant at the $99 \%(95 \%)$ confidence level. 